\title{
Dynamics of environmental conditions during the decline of a Cymodocea nodosa meadow
}

\author{
Mirjana Najdek $^{1}$, Marino Korlević ${ }^{1}$, Paolo Paliaga ${ }^{2}$, Marsej Markovski ${ }^{1}$, Ingrid Ivančić ${ }^{1}$, Ljiljana Iveša $^{1}$, Igor Felja ${ }^{3}$, \\ and Gerhard J. Herndl ${ }^{4,5}$ \\ ${ }^{1}$ Center for Marine Research, Ruđer Bošković Institute, G. Paliaga 5, 52210 Rovinj, Croatia \\ ${ }^{2}$ Department of Natural and Health Sciences, University of Pula, Zagrebačka 30, 52100 Pula, Croatia \\ ${ }^{3}$ Department of Geology, Faculty of Science, University of Zagreb, Horvatovac 102a, 10000 Zagreb, Croatia \\ ${ }^{4}$ Limnology and Bio-Oceanography, Centre of Functional Ecology, University of Vienna, Althanstrasse 14, \\ 1090 Vienna, Austria \\ ${ }^{5}$ NIOZ, Department of Marine Microbiology and Biogeochemistry, Royal Netherlands Institute for Sea Research, \\ Utrecht University, P.O. Box 59, Alberta, Den Burg, 1790, the Netherlands
}

Correspondence: Mirjana Najdek (najdek@cim.irb.hr)

Received: 9 December 2019 - Discussion started: 21 January 2020

Revised: 25 May 2020 - Accepted: 3 June 2020 - Published: 30 June 2020

\begin{abstract}
The dynamics of the physicochemical and biological parameters were followed during the decline of a $C y$ modocea nodosa meadow in the northern Adriatic Sea from July 2017 to October 2018. During the regular growth of C. nodosa from July 2017 to March 2018, the species successfully adapted to the changes in environmental conditions and prevented $\mathrm{H}_{2} \mathrm{~S}$ accumulation by its reoxidation, supplying the sediment with $\mathrm{O}_{2}$ from the water column and/or leaf photosynthesis. The $C$. nodosa decline was most likely triggered in April 2018 when light availability to the plant was drastically reduced due to increased seawater turbidity that resulted from increased terrigenous input, indicated by a decrease in salinity accompanied with a substantial increase in particulate matter concentration, combined with resuspension of sediment and elevated autotrophic biomass. Light reduction impaired photosynthesis of $C$. nodosa and the oxidation capability of belowground tissue. Simultaneously, a depletion of oxygen due to intense oxidation of $\mathrm{H}_{2} \mathrm{~S}$ occurred in the sediment, thus creating anoxic conditions in most of the rooted areas. These linked negative effects on the plant performance caused an accumulation of $\mathrm{H}_{2} \mathrm{~S}$ in the sediments of the $C$. nodosa meadow. During the decay of aboveground and belowground tissues, culminating in August 2018, high concentrations of $\mathrm{H}_{2} \mathrm{~S}$ were reached and accumulated in the sediment as well as in bottom waters. The influx of oxygenated waters in September 2018 led to the re-establishment of $\mathrm{H}_{2} \mathrm{~S}$
\end{abstract}

oxidation in the sediment and remainder of the belowground tissue. Our results indicate that if disturbances of environmental conditions, particularly those compromising the light availability, take place during the recruitment phase of plant growth when metabolic needs are at a maximum and stored reserves minimal, a sudden and drastic decline of the seagrass meadow occurs.

\section{Introduction}

Seagrasses are important ecosystem engineers, constructing valuable coastal habitats which play a key role in the preservation of marine biodiversity and carbon sequestration (Duarte et al., 2013; Samper-Villareal et al., 2016). Seagrasses extend their active metabolic surfaces (i.e., leaves, rhizomes and roots) into the water column and in the sediment, where root activity might modify the chemical conditions (Marbà and Duarte, 2001). Their canopies and dense meadows are responsible for trapping substantial amounts of sediment particles and organic matter, enhancing water transparency and sediment stability with the dense network formed by the rhizome (Gacia and Duarte, 2001; Hendriks et al., 2008; Widdows et al., 2008). Seagrass rhizospheres store organic matter (Pedersen et al., 1997), promote sulfate reduc- 
tion (Holmer and Nielsen, 1997), release oxygen (Pedersen et al., 1998) and alter sediment redox potential.

Seagrasses require some of the highest light levels of any plant worldwide to provide oxygen to roots and rhizomes and support a large amount of nonphotosynthetic tissue (Orth et al., 2006). This makes seagrasses sensitive to environmental changes, especially those that deteriorate light availability, such as sediment loading, eutrophication or epiphyte cover on seagrass leaves (Terrados et al., 1998; Halun et al., 2002; Brodersen et al., 2015; Costa et al., 2015). Seagrasses have adapted to a highly variable light environment, providing tolerance to short-term periods of low-light conditions by balancing carbon supply and respiratory requirements. In a healthy growing population this balance is achieved by increasing the photosynthetic activity, reallocating carbohydrate reserves from rhizomes and slowing down growth rates (Collier et al., 2009). Besides metabolic and physiological changes, stress responses under poor light conditions include the shedding of leaves and shoots and production of new, altered tissue. At sublethal light levels, these changes may be permanent. Below these species-specific minimum light requirements seagrass populations are dying off (Collier et al., 2012). Membrane lipids, particularly polyunsaturated fatty acids (PUFAs), as the most responsive constituents have a major role in the adaptation processes of primary producers to fluctuating environmental factors, such as temperature, irradiance or salinity (Viso et al., 1993; Lee et al., 2007; Schmid et al., 2014; Sousa et al., 2017; Beca-Carretero et al., 2018, 2019). The changes in the unsaturation degree (UND) of membrane fatty acids affect the maintenance of membrane functions and membrane resistance to cold stress or poor light conditions. The UND depends mostly on the variation in $\alpha$-linolenic (C18:3n-3; ALA) and linoleic (C18:2n-6; LA), the major unsaturated fatty acids in leaves, implicated in the evolution of oxygen during photosynthesis. LA and ALA are derived from oleic acid by desaturation in the chloroplast, and this conversion considerably declines in the dark, being completely inhibited by anaerobiosis (Harris and James, 1965).

Sediments inhabited by seagrasses are usually anoxic, highly reduced and rich in sulfide $\left(\mathrm{H}_{2} \mathrm{~S}\right)$, a strong phytotoxin (Koch and Erskine, 2001) which has been implicated in several die-off events of seagrasses (Carlson et al., 1994; Borum et al., 2005; Krause-Jensen et al., 2011). $\mathrm{H}_{2} \mathrm{~S}$ is produced by sulfate-reducing bacteria that use sulfate as a terminal electron acceptor for the mineralization of organic matter (Jørgensen, 1977; Capone and Kiene, 1988; Canfield et al., 1993). High $\mathrm{H}_{2} \mathrm{~S}$ concentrations may occur as a consequence of enhanced mineralization due to increased temperature, organic loading or oxygen depletion (Moeslund et al., 1994; Pérez et al., 2007; Mascaró et al., 2009). Under these conditions, sulfides may intrude into plants. Reoxidation of $\mathrm{H}_{2} \mathrm{~S}$ in the rhizosphere by the incorporation of $\mathrm{S}^{0}$ in the belowground tissue has been recognized as a major survival strategy of seagrasses in sulfidic sediments (Pedersen et al., 2004; Holmer et al., 2005; Hasler-Sheetal and Holmer, 2015). Generally, the synergistic effect of oxygen depletion and other stresses, such as sulfide toxicity, may shorten the survival of benthic communities and possibly accelerate mortality events (Vaquer-Sunyer and Duarte, 2010).

The seagrass Cymodocea nodosa (Ucria) Ascherson is a widely distributed and common species throughout the Mediterranean (Terrados and Ros, 1992; Pedersen et al., 1997; Cancemi et al., 2002; Agostini et al., 2003). For the northern Adriatic, however, only sparse data are available on the standing crop, seasonal dynamics, or natural and anthropogenic pressures supporting the ecological or conservation status of $C$. nodosa meadows (Zavodnik et al., 1998; Orlando-Bonaca et al., 2015). Although $C$. nodosa shows large phenotypic plasticity, adapting to diverse natural and anthropogenic stressors by physiological and morphological adaptations, a severe decline has been reported during the last few decades in coastal areas (Orth et al., 2006; Short et al., 2011; Tuya et al., 2002, 2014), including the northern Adriatic (Orlando-Bonaca et al., 2015, 2019). One of these declines was documented in our study performed from July 2017 to October 2018 in Saline Bay (northern Adriatic Sea). A series of monthly physicochemical and biological measurements were conducted in $C$. nodosa tissues, sediment underlying the $C$. nodosa meadow, nonvegetated sediments and surrounding water to (i) determine the link between ambient seawater and sediment environmental factors influencing the growth of $C$. nodosa, (ii) document the response of $C$. nodosa to the changes in environmental conditions that led to the meadow decline, and (iii) evaluate the conditions that led to a decline in C. nodosa.

\section{Materials and methods}

\subsection{Study site}

Saline Bay is located $4 \mathrm{~km}$ northwest of Rovinj (Croatia) at the coast of the northern Adriatic Sea $\left(45^{\circ} 7^{\prime} 5^{\prime \prime} \mathrm{N}\right.$, $13^{\circ} 37^{\prime} 20^{\prime \prime}$ E; Fig. S1 in the Supplement). The bay represents the terminal shallow part of an $800 \mathrm{~m}$ long inlet, open towards the northwest. The southeastern coast of Saline Bay is characterized by relatively pristine conditions, while the northwestern littoral part has been completely modified by the excavation of coastal mud and the addition of large amounts of gravel to create an artificial beach. Large amounts of silty red soil (terra rossa) can be found in the southeastern inner part of the bay in a large muddy flatland which is slowly being eroded by the sea and rain weathering. The main input of freshwater to the bay has been represented by land drainage canals since the year 2017. Even though Saline Bay is protected from the prevailing winds (from the NE and $\mathrm{SE}$ ), circulations from the northwestern quadrant can occasionally trigger bigger waves, resuspending the surface sediments and giving the waters a muddy appearance. At the 
beginning of this study, the seafloor was covered with large C. nodosa meadows spreading from the southwestern coastal area $(1.5 \mathrm{~m}$ depth) towards the central part of the bay $(4 \mathrm{~m}$ depth), while at the end of the study only a few small patches persisted in tiny stripes along the shoreline.

\subsection{Sampling}

The sampling was performed for 15 months from July 2017 to October 2018. Seawater for analyses of nutrients, chlorophyll $a(\mathrm{Chl} a)$, particulate matter concentration and prokaryotic abundance was sampled using plastic containers $(10 \mathrm{~L})$. C. nodosa (3-4 m of depth) was collected together with rhizomes, roots and epiphytic macroalgae by divers using the quadrat sampling method. Three quadrats $(20 \mathrm{~cm} \times 20 \mathrm{~cm})$ were randomly scattered in positions of maximum seagrass coverage (e.g., $100 \%$ ). Sediment samples were collected inside vegetated and nonvegetated sediment by divers using plastic core samplers $\left(15 \mathrm{~cm}, 15.9 \mathrm{~cm}^{2}\right)$. For granulometric composition, organic matter, prokaryotic abundance, total lipid and fatty acid analyses, the cores were cut into $1 \mathrm{~cm}$ sections to a depth of $8 \mathrm{~cm}$ and lyophilized, except for sections for prokaryotic abundance analysis, which were weighted (approx. $2 \mathrm{~g}$ ) and fixed with formaldehyde (final conc. $4 \% v / v$ ) immediately after slicing the sediment core.

\subsection{Temperature $(T)$ and salinity $(S)$ measurements}

$T$ was measured continuously (at $30 \mathrm{~min}$ intervals) using HOBO Pendant Temperature/Light data loggers (Onset, USA) which were replaced at each sampling. $S$ was measured on sampling dates by a pIONeer 65 probe (Radiometer Analytical, Copenhagen).

\subsection{Inorganic nutrients, $\mathrm{Chl} a$ and particulate matter (PM) analysis}

Seawater for all analysis was filtered through combusted Whatman GF/F filters. Nitrate $\left(\mathrm{NO}_{3}\right)$, nitrite $\left(\mathrm{NO}_{2}\right)$, ammonia $\left(\mathrm{NH}_{4}\right)$, phosphate $\left(\mathrm{PO}_{4}\right)$ and silicate $\left(\mathrm{SiO}_{4}\right)$ were analyzed spectrophotometrically according to Strickland and Parsons (1972). Chl $a$ was determined on filters by the fluorometric procedure after extraction in $90 \%$ acetone (HolmHansen et al., 1965). PM was determined gravimetrically after filtering up to $5 \mathrm{~L}$ of seawater on preweighed filters which were dried (at $60^{\circ} \mathrm{C}$ ) and reweighed.

\subsection{Determining prokaryotic abundance}

For determining the prokaryotic abundance in seawater, $2 \mathrm{~mL}$ of formaldehyde (final conc. $4 \% v / v$ ) fixed samples were stained with 4',6-diamidino-2-phenylindol (DAPI; $1 \mu \mathrm{g} \mathrm{mL}{ }^{-1}$ final conc.) for $10 \mathrm{~min}$ (Porter and Feig, 1980). In sediment samples, prokaryotes were detached from the sediment particles by the addition of Tween $80(0.05 \mathrm{~mL})$ and ultrasonicated for $15 \mathrm{~min}$ (Epstein and Rossel, 1995).
After sonication, $1 \mathrm{~mL}$ of the supernatant was stained with DAPI (final conc. $5 \mu \mathrm{g} \mathrm{mL}{ }^{-1}$ ). DAPI-stained samples were filtered onto black polycarbonate filters (Whatman, Nuclepore, $0.22 \mu \mathrm{m})$ and counted under an epifluorescence microscope (Zeiss AxioImager Z1).

\subsection{Biometry of $C$. nodosa and epiphytic macroalgae}

The material from each quadrat was washed under running seawater to remove sediment. From each quadrat, algae, leaves and rhizomes with roots were separated. The length of the longest leaf on each shoot was measured, and the shoots were counted. Species of macroalgae were determined, and their coverage was estimated according to the Braun-Blanquet scale. Separated samples were washed with filtered and autoclaved seawater, weighed, dried at $60^{\circ} \mathrm{C}$ for $48 \mathrm{~h}$, and reweighed. The dry mass was calculated per area $\left(\mathrm{g} \mathrm{m}^{-2}\right)$.

\subsection{Granulometric composition of the sediment and its organic matter content}

For granulometric analysis of the sediment, each sample was wet sieved through a set of seven standard ASTM sieves $(4,2,1,0.5,0.25,0.125,0.063 \mathrm{~mm}$ mesh size). The fraction that passed through the $0.063 \mathrm{~mm}$ sieve was collected and analyzed following the standard SediGraph procedure (Micromeritics, 2002). The material that was retained on the sieves was dried and weighted. The data obtained by both techniques were merged to obtain a continuous grain size range and analyzed with the statistical package GRADISTAT v 6.0. Sediments were classified according to Folk (1954). The sediment permeability was calculated based on median grain size $\left(d_{\mathrm{g}}\right)$ following the empirical relation by Gangi (1985). The organic matter content was determined as ignition loss after heating dried sediment sections at $450^{\circ} \mathrm{C}$ for $4 \mathrm{~h}$ in a muffle furnace.

\subsection{Oxygen $\left(\mathrm{O}_{2}\right)$, hydrogen sulfide $\left(\mathrm{H}_{2} \mathrm{~S}\right)$ and redox potential $\left(E_{h}\right)$ profiling}

The microprofiles of $\mathrm{O}_{2}, \mathrm{H}_{2} \mathrm{~S}$ and $E_{h}$ were measured on intact cores immediately after sampling using a motorized micromanipulator (MMS9083) equipped with microsensors OX-100 and $\mathrm{H}_{2} \mathrm{~S}-200$, a redox microelectrode RD-200 coupled with reference electrode REF-RM (Unisense A/S, Denmark). Prior to the measurements, the OX-100 microsensor was calibrated using two-point oxic-anoxic calibration; $\mathrm{H}_{2} \mathrm{~S}$ 200 was calibrated in fresh $\mathrm{Na}_{2} \mathrm{~S}$ solutions using eight-point calibration (1-300 $\mu \mathrm{M}$ in a deoxygenated calibration buffer (NaAc-HAc, $\mathrm{pH}<4$ ); RD-200 with REF-RM was calibrated using two-point calibration by the simultaneous immersion of electrodes in quinhydrone redox buffers prepared in $\mathrm{pH} 4$ and $\mathrm{pH} 7$ buffers, all according to the manufacturer's recommendations. During measurements, sediment cores were placed in a pool filled with seawater from the sampling site 
to maintain in situ temperature. From July to October 2017 $\mathrm{H}_{2} \mathrm{~S}$ was measured spectrophotometrically in pore waters (Cline, 1969) squeezed out by centrifugation from each section $(5 \mathrm{~mm})$ of the sediment cores.

\subsection{Total lipids, fatty acid composition and elemental sulfur $\left(\mathbf{S}^{\mathbf{0}}\right)$}

Lyophilized samples of seagrass tissues, macroalgae, sediment or particulate matter were weighed and extracted into a solvent mixture of dichloromethane/methanol (DCM: $\mathrm{MeOH} ; 2: 1$ ) in an ultrasonic bath at $35^{\circ} \mathrm{C}$ with three solvent mixture changes. The extracts were pooled and separated into layers by the addition of $0.9 \% \mathrm{NaCl}$ solution. Lower DCM layers (containing lipids) were released over $\mathrm{Na}_{2} \mathrm{SO}_{4}$ anhydride, collected in preweighed round bottom flasks and evaporated to dryness using a rotary evaporator. After evaporation, flasks were reweighed, and total lipid concentrations (TLs; $\mathrm{mg} \mathrm{g}^{-1} \mathrm{DW}$, where DW is dry weight) were calculated from the difference in weight. For fatty acid determination, lipid extracts were saponified $(1.2 \mathrm{M} \mathrm{NaOH}$ in methanol), acidified $(6 \mathrm{M} \mathrm{HCl})$, methylated $\left(14 \% \mathrm{BF}_{3}\right.$ in methanol) and extracted into DCM.

Fatty acid methyl esters (FAMEs) were analyzed by the Agilent gas-liquid chromatography (GLC) 6890N GC system equipped with a 5973 Network Mass Selective Detector, capillary column $(30 \mathrm{~m} \times 0.3 \mathrm{~mm} \times 0.25 \mu \mathrm{m}$; crosslinked $5 \%$ phenylmethylsiloxane) and ultrahigh-purity helium as the carrier gas. The GLC settings were as follows: programmed column temperature rise from $145^{\circ} \mathrm{C}$ by $4^{\circ} \mathrm{C} \mathrm{min}{ }^{-1}$ to $215^{\circ} \mathrm{C}$, then by $1^{\circ} \mathrm{C} \mathrm{min}^{-1}$ to $225^{\circ} \mathrm{C}$ and finally by $4{ }^{\circ} \mathrm{C} \min ^{-1}$ to $270^{\circ} \mathrm{C}$ at a constant column pressure of $2.17 \mathrm{kPa}$. Retention times, peak areas and mass spectra were recorded on the ChemStation Software. FAMEs were identified by mass spectral data and family plots of an equivalent chain length (ECL) for GC standards. Applied GC standards were as follows: FAME mix C18-C20, PUFA1 and PUFA3 standards (Supelco, Sigma-Aldrich, Bellefonte, PA, USA) and C4-C24 FAME standard mix, cod liver oil and various individual pure standards (Sigma, Neustadt, Germany).

The following indices of fatty acid profiles were calculated: saturated fatty acids (SATs), monounsaturated fatty acids (MUFAs), polyunsaturated fatty acids (PUFAs) and the unsaturation degree (UND). The UND was employed to evaluate the degree of organic matter degradation due to the greater susceptibility of unsaturated, particularly polyunsaturated, components to degradation and calculated according to the formula

$$
\begin{aligned}
& {[1 \cdot(\% \text { monoenoic })+2 \cdot(\% \text { dienoic })+3 \cdot(\% \text { trienoic })} \\
& \quad+4 \cdot(\% \text { tetraenoic })+5 \cdot(\% \text { pentaenoic }) \\
& \quad+6 \cdot(\% \text { hexaenoic })] / \% \text { SAT }
\end{aligned}
$$

(Pirini et al., 2007). To evaluate the input of terrestrial organic matter relative to that of marine organic matter in par- ticulate matter, the ratio of terrestrial to aquatic acid (TAR $=$ $\mathrm{C} 24+\mathrm{C} 26+\mathrm{C} 28 / \mathrm{C} 12+\mathrm{C} 14+\mathrm{C} 16)$ was used (Cranwell et al., 1987; Bourbonniere and Meyers, 1996).

In FAMEs, chromatograms elemental sulfur $\left(\mathrm{S}^{0}\right)$, eluted as $\mathrm{S}_{8}(m / z 256)$, was identified by the comparison of retention time with characteristic fragment ions in samples and standard solutions. The concentration of $S^{0}$ was estimated on the base of the calibration curve prepared for standard solution of $\mathrm{S}_{8}$ (Aldrich, Germany) in cyclohexane $\left(2-20 \mathrm{mg} \mathrm{L}^{-1}\right)$. The calibration curve was determined under the same GLC settings as for FAMEs. The limit of detection (LoD) and limit of quantitation (LoQ) were calculated from the parameters of the calibration curve constructed on the basis of the three lowest concentrations in three replicates. The LoD and LoQ (0.92 and $2.80 \mathrm{mg} \mathrm{L}^{-1}$, respectively) were more than twice the values obtained by Rogowska et al. (2016) probably due to the higher injector and column temperature used in this study than the one they proposed as optimal for S determination.

\subsection{Data analyses}

A multivariate analysis, hierarchical clustering and $k$-means methods (SYSTAT 12) were applied to group C. nodosa aboveground and belowground tissues according to the similarity of their fatty acid profiles and indices, i.e., physiological condition, during the investigated period.

Sediment data were analyzed for two groups of sediment layers, the upper layer $(0-4 \mathrm{~cm})$, where most of the rhizomes and roots are located, and the lower layers $(5-7 \mathrm{~cm})$. Differences between vegetated and nonvegetated sediment samples in each sediment layer were tested by one-way ANOVA. Correlations among parameters were tested using the Pearson's correlation coefficient $(r)$. The level of statistical significance was $p<0.05$. A multivariate principal component analysis (PCA; PRIMER 6) was applied to identify the most important variables explaining differences between vegetated and nonvegetated sediments. Correlation matrices were constructed using the following variables: $\mathrm{H}_{2} \mathrm{~S}, E_{h}, \mathrm{O}_{2}, \mathrm{~S}^{0}$, prokaryotic abundance (PA), TL and UND. All variables were normalized due to their different scales. Only the principal components with eigenvalues $>1$ were considered.

\section{Results}

\subsection{Water column}

\section{Environmental variables}

During the summer of 2017 daily means of sea-bottom temperature in the $C$. nodosa meadow ranged between 26 and $28^{\circ} \mathrm{C}$. During autumn seawater temperatures decreased, reaching below $12^{\circ} \mathrm{C}$ by the end of December. The coldest period was recorded at the beginning of March lasting only for a few days $\left(\min 8.62^{\circ} \mathrm{C}\right)$. From April to mid-July 2018, 
(a)

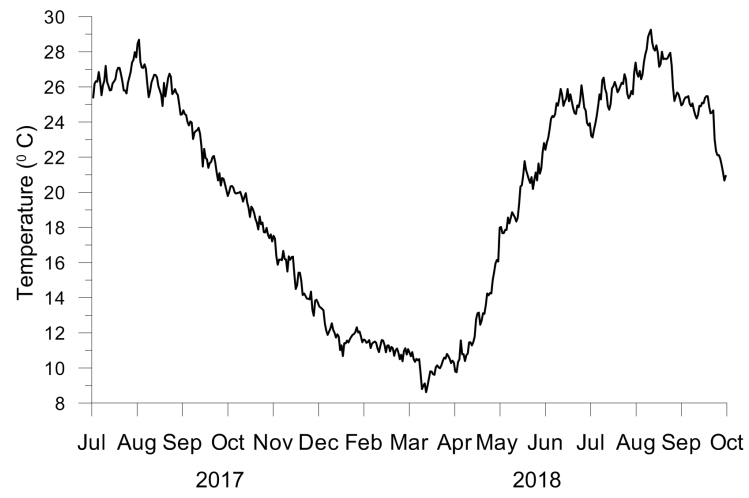

(b)

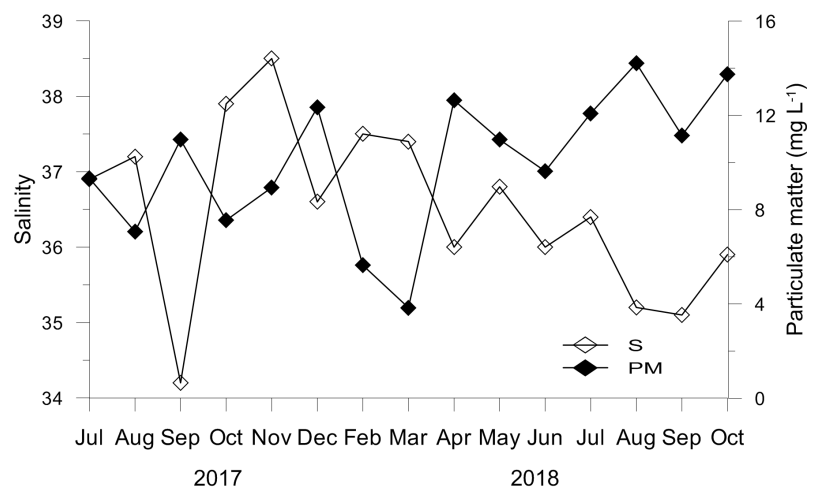

(c)

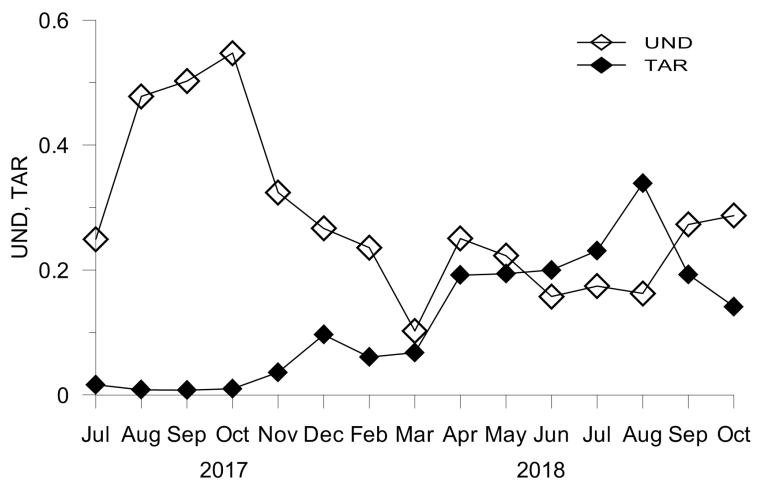

Figure 1. Temperature (a), salinity and particulate matter concentration (b), and unsaturation degree (UND) and terrestrial-toaquatic ratio (TAR) of the particulate lipid matter (c) in seawater.

temperature increased with moderate fluctuations to the maximum of $29.26^{\circ} \mathrm{C}$ recorded in August 2018 (Fig. 1a).

Concentrations of inorganic nutrients and $\mathrm{Chl} a$ were generally low. The highest concentrations (DIN $-8.27 \mu \mathrm{M} ; \mathrm{PO}_{4}$ $-0.18 \mu \mathrm{M} ; \mathrm{SiO}_{4}-9.82 \mu \mathrm{M} ; \mathrm{Chl} a-0.89 \mu \mathrm{g} \mathrm{L}^{-1}$ ) associated with the lowest salinity (34.2) were found in September 2017 (Table S1 in the Supplement). The abundance of prokaryotes $\left(2.6-11.3 \times 10^{5}\right.$ cell $\left.\mathrm{mL}^{-1}\right)$ varied seasonally and significantly correlated to seawater temperatures $(r=0.618$; $p<0.05)$. In contrast, salinity $(S: 34.2-38.5)$ and concentrations of particulate matter (PM: $3.84-14.21 \mathrm{mg} \mathrm{L}^{-1}$ ) showed irregular variations (Fig. 1b) and a significant opposite trend $(r=-0.630 ; p<0.05)$.
The particulate lipids exhibited the highest unsaturation degree (UND) during summer and early autumn 2017 and small increases in the UND in April and September and October 2018 (Fig. 1c). The UND was significantly correlated with Chl $a(r=0.603 ; p<0.05)$. In contrast, the terrestrialto-aquatic ratio (TAR) considerably increased in April and was the highest in August 2018 (Fig. 1c). TAR was correlated negatively to the UND $(r=-0.644 ; p<0.05)$ and positively to particulate matter $(r=0.641 ; p<0.05)$. Although PUFA with $18 \mathrm{C}$ atoms (C18 PUFA) made the largest contribution to the total PUFA pool, C20 PUFA, mainly of phytoplankton origin, showed a similar trend to that observed for the UND (Fig. S2, Table S2).

\subsection{Cymodocea nodosa meadow}

\subsubsection{Biometry}

C. nodosa leaves and shoots reached the highest biomass $\left(285.3 \pm 57.4 \mathrm{~g} \mathrm{~m}^{-2}\right)$, length $(102.4 \pm 26.6 \mathrm{~mm})$ and shoot density $\left(3703 \pm 334\right.$ shoots $\left.\mathrm{m}^{-2}\right)$ in October 2017 (Fig. 2a). After the appearance of the regular vegetation minimum in November 2017, biometric indices further decreased reflecting the decay of the meadow in summer 2018. In August 2018, only yellow to brownish leaves on sparse shoots were collected $\left(4.5 \pm 1.3 \mathrm{~g} \mathrm{~m}^{-2}, 5.4 \pm 1.3 \mathrm{~mm}\right.$ and $30 \pm 35$ shoots $\mathrm{m}^{-2}$ ). In September and October 2018, no shoots or leaves were observed (Fig. 2a). The biomass of rhizomes and roots also reached its maximum in October 2017 $\left(599.7 \pm 36.8 \mathrm{~g} \mathrm{~m}^{-2}\right)$. In contrast to leaves and shoots, the belowground biomass was stable until March 2018 when a decline was observed that continued until October 2018 $\left(30.5 \pm 6.8 \mathrm{~g} \mathrm{~m}^{-2}\right.$; Fig. 2a).

\subsubsection{Total lipid concentrations (TLs) and fatty acid composition}

$\mathrm{TL}$ in the $C$. nodosa aboveground tissue (6.7$25.3 \pm 2.4 \mathrm{mg} \mathrm{g}^{-1} \mathrm{DW}$ ) increased until February 2018, when maximum TLs were measured (Fig. 2b). Thereafter, TLs decreased until August 2018. During this period, the belowground TL $\left(6.3 \pm 1.9-15.9 \pm 1.1 \mathrm{mg} \mathrm{g}^{-1} \mathrm{DW}\right)$ was generally lower than the aboveground TLs and the trend was similar to that of leaves. The minimum TLs were observed in September 2018, while in October 2018, concentrations similar to that measured in October 2017 were observed (Fig. 2b).

The major fatty acid components in $C$. nodosa tissues were palmitic (C16:0) among the saturated fatty acids (SATs) and oleic $(\mathrm{C} 18: 1 n-9)$ in monounsaturated fatty acids (MUFAs). In the aboveground tissue, the main polyunsaturated fatty acids (PUFAs) were $\alpha$-linolenic (C18:3n-3; ALA) and linoleic (C18:2n-6; LA), while in the belowground tissue LA was dominant (Fig. 2b). The dynamics of the UND in the aboveground tissue was principally influenced by changes in 
(a)

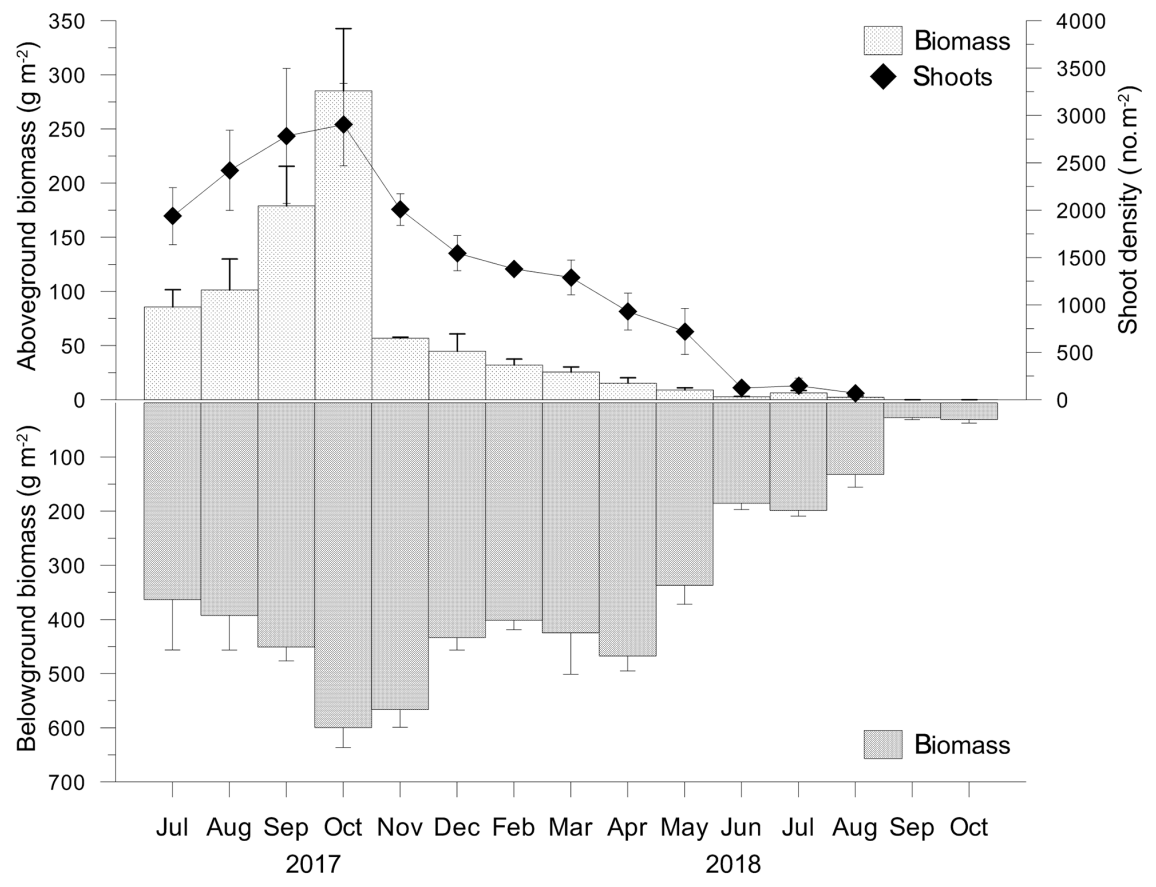

(b)

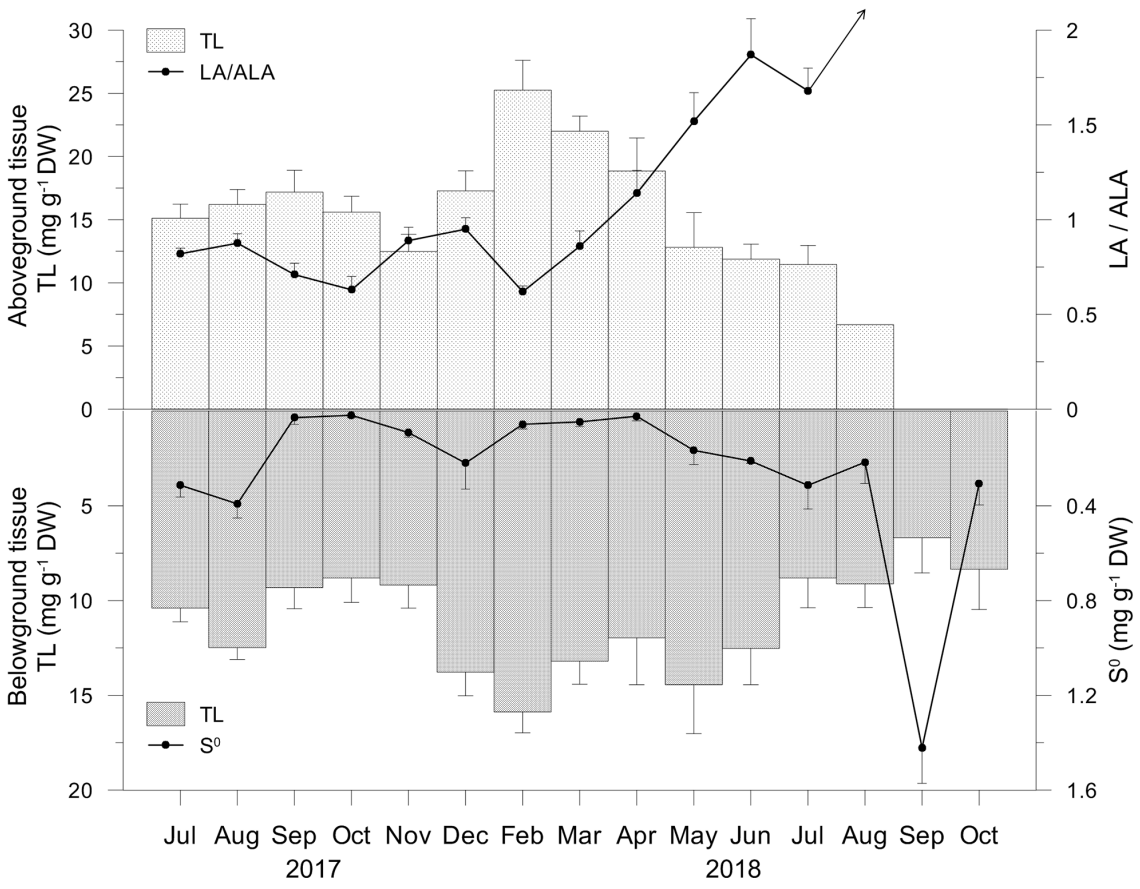

Figure 2. Aboveground and belowground tissue biomasses and shoot density (a), total lipid concentrations (TLs) and linoleic-to- $\alpha$-linolenic fatty acid ratios (LA / ALA; an arrow indicates an infinite value) in aboveground tissue and TLs and approximated concentrations of elemental sulfur $\left(S^{0}\right)$ in belowground tissue (b).

ALA and LA. LA / ALA ratios were $<1$ from July 2017 to March 2018 and $>1$ from April to July 2018 (Fig. 2b). In August 2018, the LA / ALA ratio was infinite due to the absence of ALA (Fig. 2b). Elemental sulfur $\left(\mathrm{S}^{0}\right)$ was detected only in decaying leaves in August $2018\left(0.21 \mathrm{mg} \mathrm{g}^{-1} \mathrm{DW}\right)$. In the belowground tissue, $S^{0}$ was detected in all samples (Fig. 2b). Higher concentrations were measured during sum- mer 2017 (up to $0.39 \pm 0.06 \mathrm{mg} \mathrm{g}^{-1} \mathrm{DW}$ ). $\mathrm{S}^{0}$ increased from minimum concentrations in April $\left(0.02 \pm 0.01 \mathrm{mg} \mathrm{g}^{-1} \mathrm{DW}\right)$ until reaching $1.42 \mathrm{mg} \mathrm{g}^{-1} \mathrm{DW}$ in September 2018 (Fig. 2b).

According to the fatty acid profiles, $C$. nodosa leaves were classified into three groups, except for the leaves collected in August 2018 (Fig. 3). The most distinguishing features specifying physiological differences between 


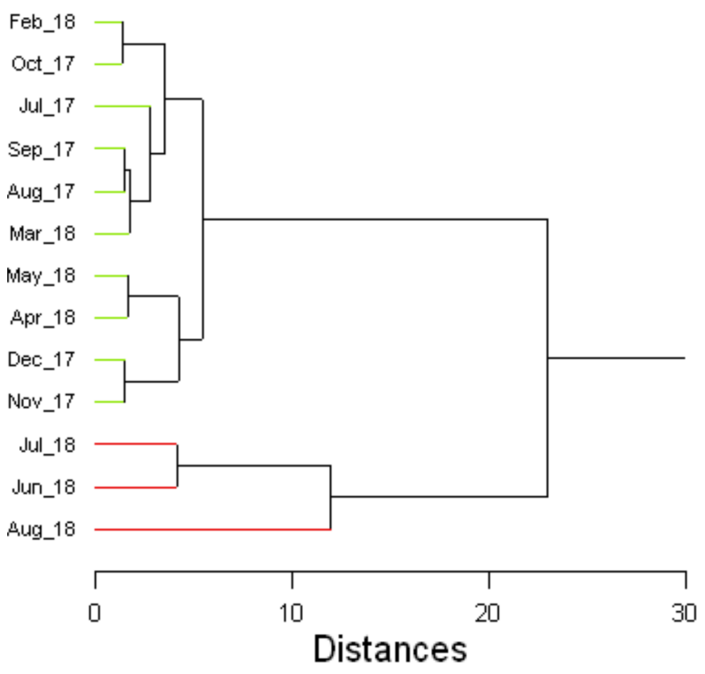

Figure 3. Cluster analysis dendrogram of the fatty acid composition of $C$. nodosa leaves. Summary statistics are given in Table S3.

Group 1 (July-October 2017 and February-March 2018), Group 2 (November-December 2017 and April-May 2018) and Group 3 (June and July 2018) were decreasing mean values of PUFA, UND, ALA and LA and increasing means of SAT and the proportion of long-chain saturated fatty acids $(C \geq 24)$. In the ungrouped leaves from August 2018 ALA was not found and PUFA and UND were at a minimum, while SAT and $\mathrm{C} \geq 24$ were at a maximum (Table S3). Three groups of rhizomes and roots (Group 1 July-October 2017 and February-March 2018; Group 2 November-December 2017 and April-May 2018; Group 3 - June-October 2018) showed similar characteristics to the groups 1, 2 and 3 of related leaves (Table S4).

\subsubsection{Epiphytic macroalgae}

From July 2017 to February 2018 different taxa of macroalgae belonging to the three phyla Chlorophyta (Halimeda tuna, Dasycladus vermicularis, Cladophora prolifera, Udotea petiolata), Rhodophyta (Rytiphlaea tinctoria, Peyssonnelia spp., Gelidium sp.) and Ochrophyta (Dictyota dichotoma) covered the meadow in varying proportions and abundances (Fig. 4). After March 2018, when only few individuals of Peyssonnelia sp. were found, macroalgae were no longer present in the $C$. nodosa meadow.

Although the fatty acid profiles of macroalgal communities were highly variable, the contribution of C18 PUFA and C20 PUFA to the total PUFA pool generally depended on the prevailing phyla and their characteristic PUFA pattern. The algae belonging to Rhodophyta and Ochrophyta are richer in C20 PUFA (C20:5n-3, C20:4n-6), while Chlorophyta generally show a prevalence of C18 PUFA (C18:3n-3, C18:2n-6; Schmid et al., 2014; Gao et al., 2018). Furthermore, their contribution to biomass varied due to large differences in morphology, which most likely also contributed to

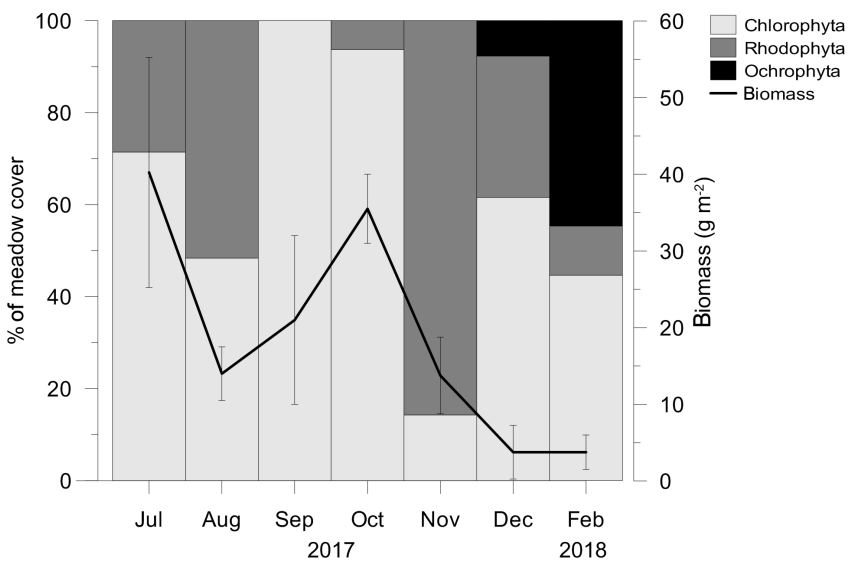

Figure 4. The contribution of macroalgal phyla in a meadow cover and total macroalgal biomass. After February 2018 macroalgae were no longer present in the $C$. nodosa meadow.

the variability in fatty acid profiles. During the dominance of Chlorophyta and Rhodophyta in the macroalgal community, C18 PUFA and C20 PUFA, respectively, showed the highest contribution to the total PUFA pool. In most samples, the lowest contribution to the total PUFA pool was observed for C16 PUFA and C22 PUFA (Fig. S3).

\subsection{Sediment}

\subsubsection{Granulometric composition}

According to the granulometric composition, median grain sizes $\left(d_{\mathrm{g}}\right)$ and permeability $(k)$, the vegetated and nonvegetated sediments were classified as slightly gravelly sandy mud, fine-grained sediment $\left(d_{\mathrm{g}}<165 \mu \mathrm{m}\right)$ and lowpermeability sediment to impermeable sediment $(k<2 \times$ $10^{-11} \mathrm{~m}^{2}$ ). In general, the $C$. nodosa sediment consisted of a significantly higher proportion of sand $(\mathrm{Sa})$ and lower proportion of silt ( $\mathrm{Si}$ ) and clay (C; $\mathrm{Sa}, 41.11 \pm 4.34 \%$; $\mathrm{Si}$, $46.44 \pm 2.86 \%$; $\mathrm{C}, 9.63 \pm 2.76 \%)$ in comparison to nonvegetated sediment ( $\mathrm{Sa}, 20.53 \pm 10.49 \%$; Si, $53.24 \pm 6.76 \%$; , $23.29 \pm 4.86 \%$ ). The median grain size and permeability in C. nodosa sediment $\left(d_{\mathrm{g}}, 37.51 \pm 17.97 \mu \mathrm{m} ; k, 1.22 \times 10^{-12} \pm\right.$ $1.13 \times 10^{-12} \mathrm{~m}^{2}$ ) were significantly higher than in nonvegetated sediment $\left(d_{\mathrm{g}}, 10.86 \pm 5.34 \mu \mathrm{m} ; k, 1.04 \times 10^{-13} \pm 1.02 \times\right.$ $\left.10^{-13} \mathrm{~m}^{2}\right)$. The upper layers of both cores $(0-4 \mathrm{~cm})$ had larger particles, while the lower layers $(5-8 \mathrm{~cm})$ showed a uniform distribution of smaller grain sizes (Fig. 5).

\subsection{2 $\mathrm{O}_{2}, E_{h}, \mathrm{H}_{2} \mathrm{~S}$ and $\mathrm{S}^{0}$}

Oxygen concentrations $\left(\mathrm{O}_{2}\right)$ in the bottom water of the $C$. nodosa meadow varied over a wide range $(0 \mu \mathrm{M}-$ $171.4 \pm 17.6 \mu \mathrm{M})$ and generally followed the $\mathrm{O}_{2}$ saturation trend (Fig. 6a). From May to June 2018, $\mathrm{O}_{2}$ decreased to below $62.5 \mu \mathrm{M}$, considered as severe hypoxia (Vaquer-Sunyer and Duarte, 2008), and was completely depleted in July 2018 


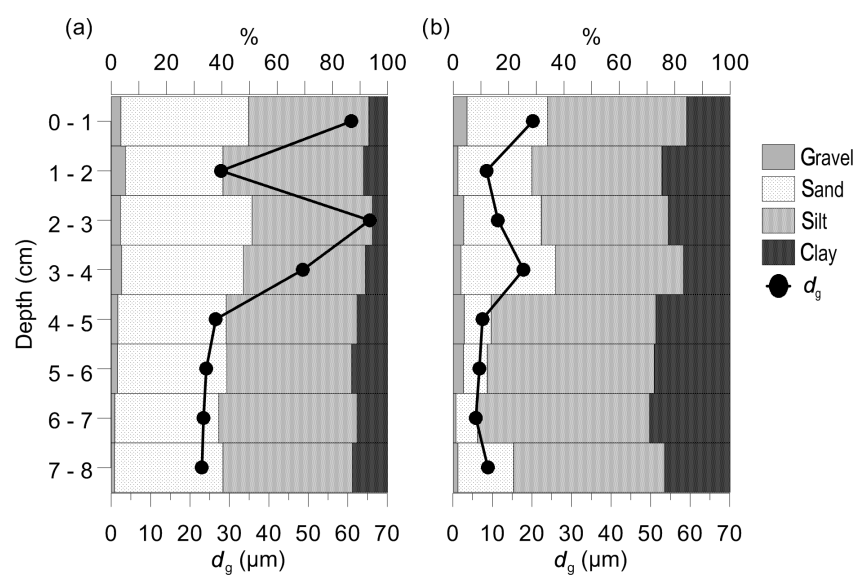

Figure 5. Granulometric composition and median grain size $\left(d_{\mathrm{g}}\right)$ of vegetated (a) and nonvegetated sediment (b).

(Fig. 6a). From August to October 2018, $\mathrm{O}_{2}$ increased again. The variations of $\mathrm{O}_{2}$ in the bottom water of the nonvegetated sediment were similar to those in the $C$. nodosa meadow albeit generally higher $(79.4 \pm 10.4 \mu \mathrm{M}-212.2 \pm 33.4 \mu \mathrm{M})$ than in the vegetated sediment except for in September and October 2018 (Fig. 6a).

In general, the $\mathrm{O}_{2}$ penetration depth in the vegetated and nonvegetated sediment covaried with the $\mathrm{O}_{2}$ concentration in the bottom layer, penetrating deeper when its concentration in the bottom water was higher (Fig. 6b). In the vegetated sediment, $\mathrm{O}_{2}$ was mainly depleted down to $1 \mathrm{~cm}$ of depth. In the nonvegetated sediment, the oxygen penetration depth was up to 4 times higher than in vegetated sediments, except for the period from August to October 2018 when the penetration depths were similar (Fig. 6b).

The thickness of the oxic $\left(E_{h}>150 \mathrm{mV}\right)$ and suboxic $\left(150 \mathrm{mV}>E_{h}>0 \mathrm{mV}\right)$ layers in the vegetated sediment increased from July $2017(\sim 0.5 \mathrm{~cm})$ to March $2018(\sim 4 \mathrm{~cm})$ and decreased progressively from April $(\sim 0.8 \mathrm{~cm})$ towards the surface in July 2018, when the entire sediment core was anoxic $\left(E_{h}<0\right)$. From August $(\sim 1 \mathrm{~cm})$ to October 2018 $(\sim 2.5 \mathrm{~cm})$ the oxic and suboxic layer thickness increased again (Fig. 7). Oxic conditions $\left(E_{h}>0\right)$ generally reflected $\mathrm{O}_{2}$ concentrations in the bottom waters. The dynamics of $E_{h}$ in nonvegetated sediment were similar to those in the vegetated sediment. However, the thickness of the oxic layer was considerably larger than in the vegetated sediment. Reducing conditions $\left(E_{h}<0\right)$ were only recorded in July and August 2017 (Fig. 7).

Concentrations of free $\mathrm{H}_{2} \mathrm{~S}$ in the pore water of the vegetated sediment generally increased with depth, creating an accumulation zone mainly within the upper sediment layers (1-4 cm; Fig. 7). From July to November 2017, $\mathrm{H}_{2} \mathrm{~S}$ concentrations increased up to $120 \mu \mathrm{M}$ (at 4-5 cm). In December 2017, $\mathrm{H}_{2} \mathrm{~S}$ was low and uniformly distributed throughout the core $(<5 \mu \mathrm{M}) . \mathrm{H}_{2} \mathrm{~S}$ concentrations increased and the ac- cumulation layer was ascending from March (up to $34.2 \pm$ $12.8 \mu \mathrm{M} ; 5-7 \mathrm{~cm}$ ) to April 2018 (up to $177.2 \pm 125.1 \mu \mathrm{M}$; $3.5-4.5 \mathrm{~cm}$ ). During May (up to $107.8 \pm 75.9 \mu \mathrm{M} ; 2.5-4 \mathrm{~cm}$ ), June (up to $199.0 \pm 6.3 \mu \mathrm{M} ; 1.5-6 \mathrm{~cm}$ ) and July (up to $210.1 \pm$ $138.9 \mu \mathrm{M}$; bottom water $-6 \mathrm{~cm}$ ) 2018 a propagation of the accumulation zone was observed in addition to an increase in $\mathrm{H}_{2} \mathrm{~S}$ (Fig. 7). In August 2018 (up to $1164.1 \pm 702.1 \mu \mathrm{M}$; bottom water $-7 \mathrm{~cm}$ ) extremely high concentrations over the entire sediment core were recorded. In September and October 2018, $\mathrm{H}_{2} \mathrm{~S}$ concentrations decreased (down to $140.0 \pm 25.3$ and $72.7 \pm 52.7 \mu \mathrm{M}$; bottom water $-7 \mathrm{~cm}$ and $1-7 \mathrm{~cm}$, respectively). In the nonvegetated sediment, $\mathrm{H}_{2} \mathrm{~S}$ depth profiles were similar to those in vegetated sediments, but the concentrations were generally lower, except for in the summer of 2017 when the concentrations were comparable but the accumulation zones deeper (Fig. 7).

$\mathrm{S}^{0}$ mainly occurred in oxic $\left(E_{h}>150 \mathrm{mV}\right)$ and suboxic $\left(150 \mathrm{mV}>E_{h}>0 \mathrm{mV}\right)$ layers of both, vegetated and nonvegetated sediments (Fig. 7). Generally, the ranges of approximated $S^{0}$ concentrations in vegetated sediment $(8.5 \times$ $\left.10^{-5}-0.39 \mathrm{mg} \mathrm{g}^{-1} \mathrm{DW}-2.6 \times 10^{-3}-12.1 \mu \mathrm{mol} \mathrm{g}^{-1} \mathrm{DW}\right)$, except for the extreme value in April $2018\left(0.99 \mathrm{mg} \mathrm{g}^{-1} \mathrm{DW}-\right.$ $30.8 \mu \mathrm{mol} \mathrm{g}^{-1} \mathrm{DW}$ ), were similar to those found at the nonvegetated sites $\left(2.9 \times 10^{-4}-0.28 \mathrm{mg} \mathrm{g}^{-1}\right.$ DW-9.2 $\times 10^{-3}$ $\left.8.9 \mu \mathrm{mol} \mathrm{g}^{-1} \mathrm{DW}\right)$.

\subsubsection{Prokaryotic abundance}

Prokaryotic abundance varied largely in vegetated (2.1$39.9 \times 10^{7}$ cells $\mathrm{g}^{-1} \mathrm{FW}$, where $\mathrm{FW}$ is fresh weight) and nonvegetated $\quad\left(3.7-24.1 \times 10^{7}\right.$ cells g $\left.^{-1} \mathrm{FW}\right)$ sediments. Prokaryotic abundance was significantly higher in the upper layers than in the lower layers of vegetated $(F=40.553$; $p<0.05)$ and nonvegetated $(F=52.531 ; p<0.05)$ sediments (Fig. 8). Prokaryotic abundance showed significant monthly changes in the upper $(F=3.053 ; p<0.05)$ and lower $(F=5.035 ; p<0.05)$ layer of vegetated sediments, in contrast to both layers of nonvegetated sediments $(p>0.05)$. Prokaryotic abundances were significantly higher in the upper layers $(F=44.577 ; p<0.05)$ and significantly lower in the lower layers $(F=5.986 ; p<0.05)$ of vegetated sediments than in the respective layers of nonvegetated sediments (Fig. 8). In the upper sediment layer, prokaryotic abundances were significantly higher in the vegetated than in the nonvegetated sediments from July to October 2017 and from June to August 2018 (Fig. 8). In the lower layers of vegetated sediments, prokaryotic abundance was significantly higher than in the nonvegetated sediments in October 2017 and in August and September 2018 (Fig. 8).

\subsubsection{Organic matter, total lipids and fatty acid composition}

The concentrations of organic matter $(\mathrm{OM})$ and total lipid concentrations (TLs) were highly correlated in vegetated 


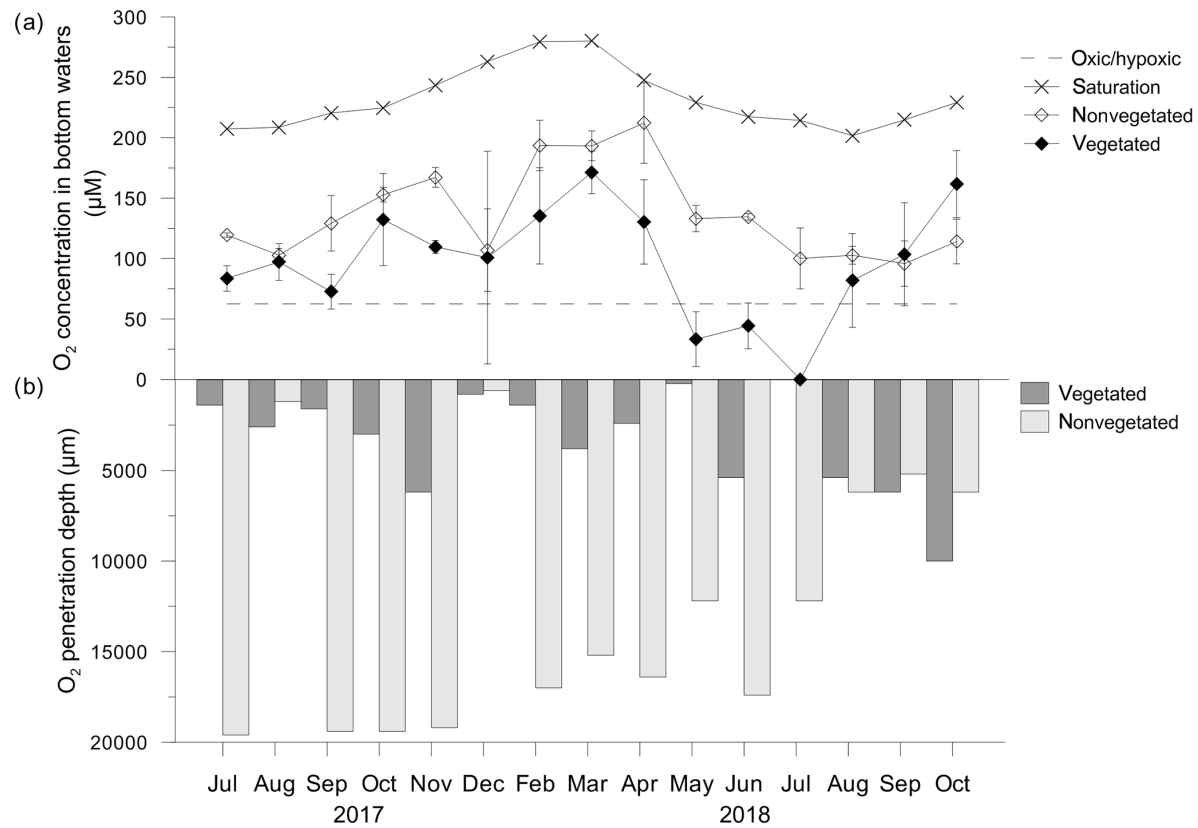

Figure 6. (a) Oxygen $\left(\mathrm{O}_{2}\right)$ concentrations in bottom waters in, and (b) $\mathrm{O}_{2}$ penetration depths above, vegetated and nonvegetated sediment. $\mathrm{O}_{2}$ at the saturation level was calculated according to the temperature and salinity measured in seawater on the sampling dates; $\mathrm{O}_{2}$ at the hypoxic frontier $(\sim 62.5 \mu \mathrm{M})$ was taken from Vaquer-Sanyer and Duarte (2008).

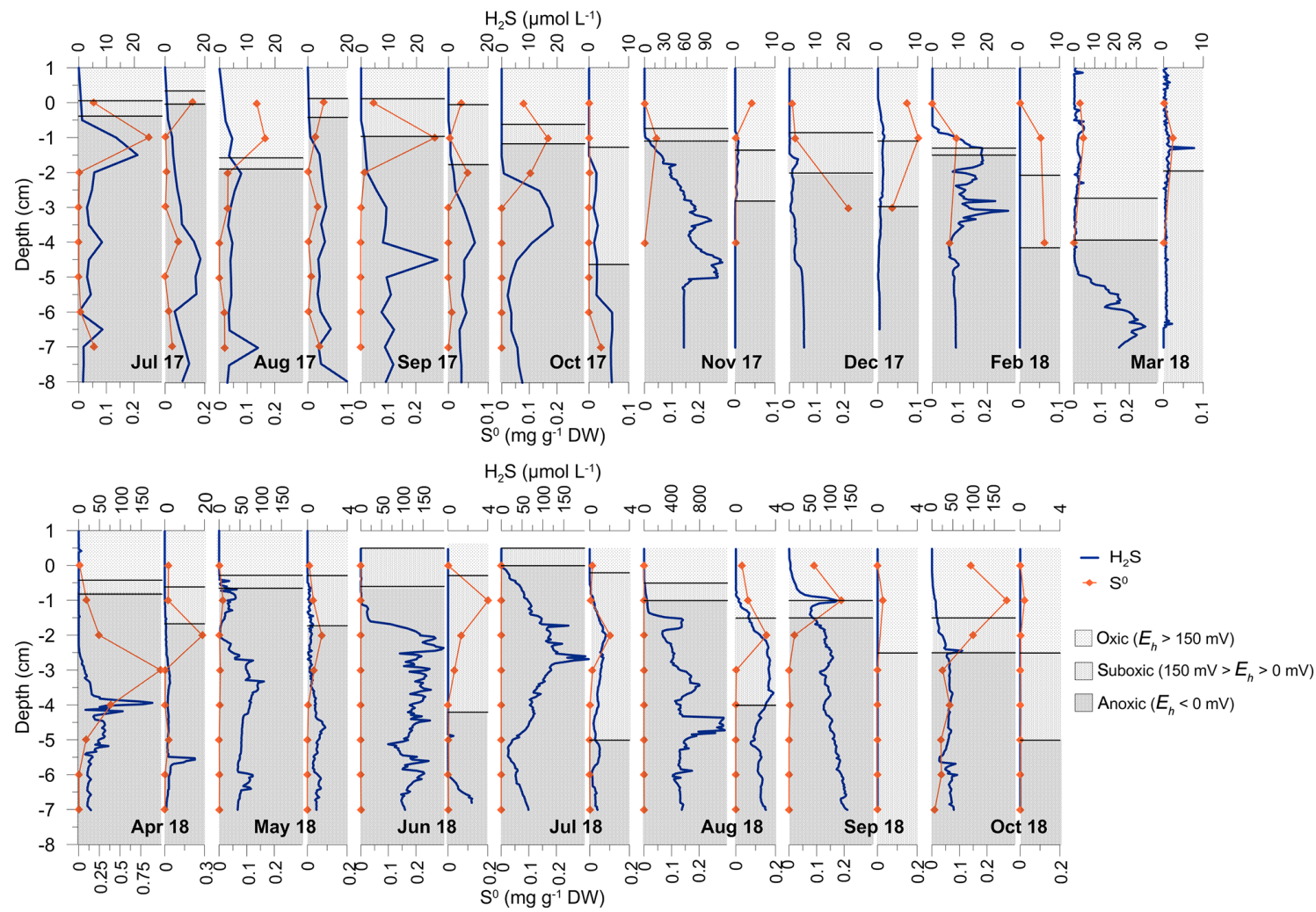

Figure 7. Depth profiles of $\mathrm{H}_{2} \mathrm{~S}$ and $\mathrm{S}^{0}$ concentrations in vegetated and nonvegetated sediment (adjacent narrow graphs). The redox potential $\left(E_{h}\right)$ in both sediments is shown as areas corresponding to oxic $\left(E_{h}>150 \mathrm{mV}\right)$, suboxic $\left(150>E_{h}>0 \mathrm{mV}\right)$ and anoxic $\left(E_{h}<0 \mathrm{mV}\right)$ conditions. 


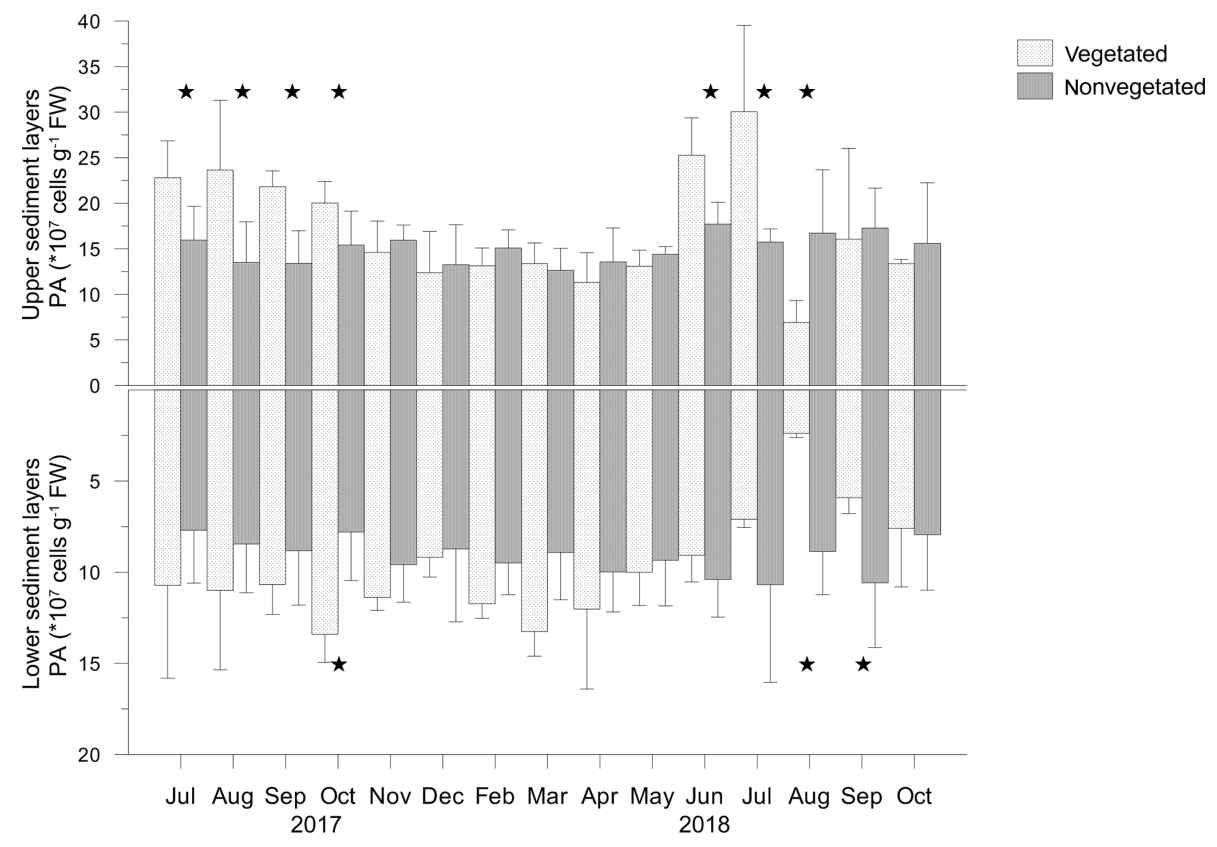

Figure 8. Prokaryotic abundance $(\mathrm{PA})$ in the upper $(0-4 \mathrm{~cm})$ and lower $(5-8 \mathrm{~cm})$ layers of vegetated and nonvegetated sediments; significant differences in PA between the sediments are indicated by stars.

$\left(\mathrm{OM}-37.6-231.1 \mathrm{mg} \mathrm{g}^{-1} \mathrm{DW}\right.$; TL $-0.15-2.75 \mathrm{mg} \mathrm{g}^{-1} \mathrm{DW}$; $F=214.172 ; p<0.05)$ as well as in nonvegetated $(\mathrm{OM}-$ $56.7-160.3 \mathrm{mg} \mathrm{g}^{-1} \mathrm{DW}$; TL $-0.33-2.39 \mathrm{mg} \mathrm{g}^{-1} \mathrm{DW} ; F=$ $45.569 ; p<0.05)$ sediments. OM and TL generally decreased with depth and exhibited similar changes throughout the investigated period with significantly higher concentrations in upper sediment layers than in lower sediment layers $(p<0.05$; Fig. 9).

In the vegetated sediment, the TL showed significant monthly changes in the upper $(F=11.418 ; p<0.05)$ and lower $(F=3.186 ; p<0.05)$ sediment layers, in contrast to both layers of nonvegetated sediment $(p>0.05)$. From July to October 2017, in the upper layer of vegetated sediments, TL was significantly higher than in nonvegetated sediments (Fig. 9). From November 2017 onwards, TL decreased slightly until April 2018, reaching similar concentrations to TL in nonvegetated sediments (Fig. 9). TLs decreased markedly in May and continued to decrease until August 2018. During that period, the TL in vegetated sediments was significantly lower than in nonvegetated sediments. In September and October 2018, TLs in vegetated sediments were similar to those in nonvegetated sediments (Fig. 9).

The fatty acid composition of vegetated and nonvegetated sediments was similar and in both layers characterized by the prevalence of SAT (vegetated upper $71.2 \%-$ $90.4 \%$, lower $75.9 \%-89.1 \%$; nonvegetated upper $71.2 \%-$ $80.7 \%$, lower $78.2 \%-82.5 \%$ ) over MUFA (vegetated upper $7.6 \%-22.9 \%$, lower $9.0 \%-19.9 \%$; nonvegetated upper $17.8 \%-24.1 \%$, lower $15.3 \%-18.2 \%$ ) and PUFA (vegetated upper $1.9 \%-6.9 \%$, lower $1.9 \%-5.1 \%$; nonvegetated upper
$1.7 \%-4.8 \%$, lower $1.7 \%-3.9 \%$ ). The trends of the monthly changes in the UND were similar in both layers of both sediment types. Those variations were less pronounced in the nonvegetated sediment where the UND varied in narrower ranges in both layers (upper 0.26-0.51, lower 0.23-0.33) than it did in vegetated sediment (upper 0.13-0.57, lower 0.14-0.37). From July to October 2017 and in April 2018, the UND was higher in the upper layers of vegetated sediment than in the nonvegetated one, while from November 2017 to March 2018, UNDs of both sediments were lower than in the previous period (Fig. 9). From June to August 2018, the UND decreased considerably in vegetated sediment, being lower than in nonvegetated sediments. During September and October 2018, an increase in the UND was observed in both sediments. In the lower layers, UNDs were similar, except for in July and August 2018 when a considerable decrease in the UND was observed in vegetated sediments (Fig. 9).

The proportions of PUFAs with chain lengths of 16, 18, 20 and $22 \mathrm{C}$ atoms within the PUFA pool were similar between the respective layers of both sediments. Throughout the study period, the highest contribution of C18 PUFA originated from C. nodosa detritus and Chlorophyta was observed (Fig. S4, Table S2). From July to October 2017, April to May 2018 and September to October 2018, a contribution of C20 PUFA attributed to phytoplankton and Rhodophyta was also detected. The smallest contribution to the PUFA pool was accounted for by C16 PUFA and C22 PUFA, which were found in seston and macroalgae (Fig. S4, Table S2).

The similarities between the sediments were also observed in the contribution of the main SAT components to the SAT 


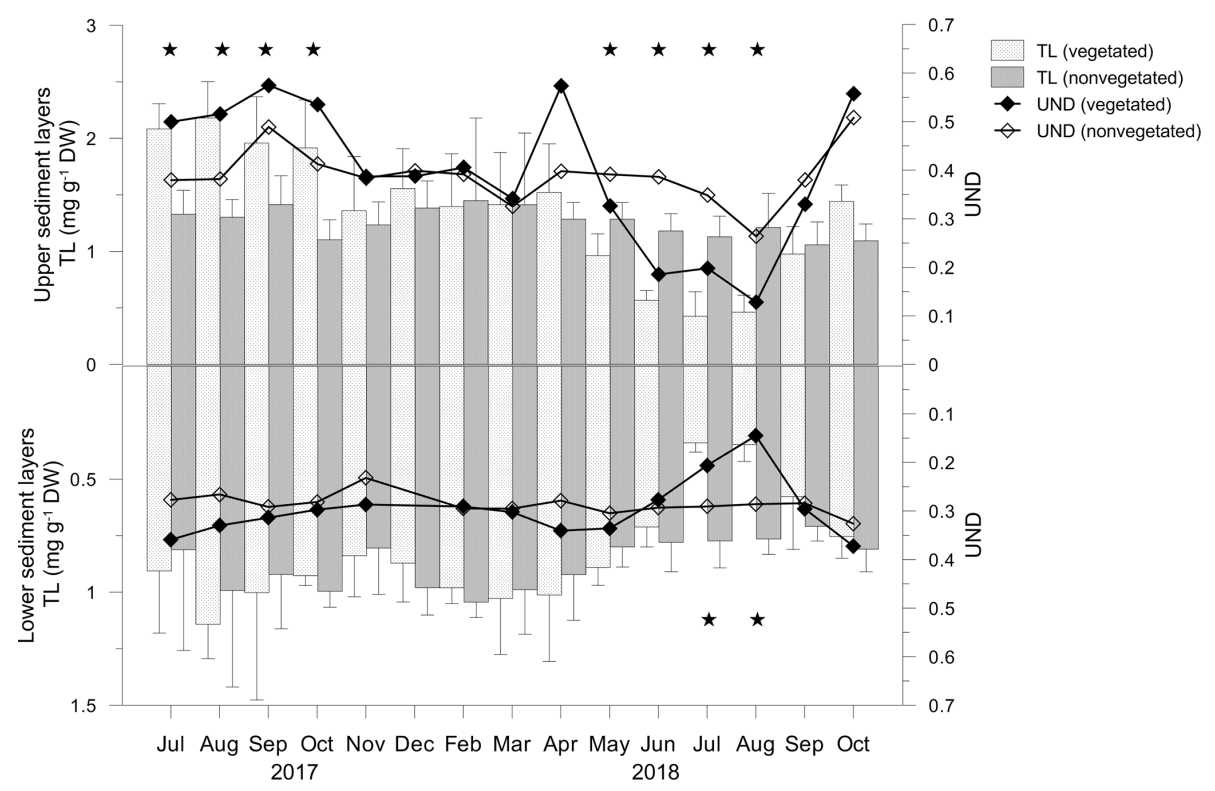

Figure 9. Total lipid concentrations (TLs) and unsaturation degree (UND) in the upper $(0-4 \mathrm{~cm})$ and lower (5-8 cm) layers of vegetated and nonvegetated sediments. Significant differences in TLs between the sediments are indicated by stars.

pool from July 2017 to March 2018 and from September to October 2018 (Fig. S4, Table S2). From April to August 2018, an increase in the long-chain $(C \geq 24)$ and common $(\mathrm{C} 16: 0+\mathrm{C} 18: 0)$ fatty acids followed by a decrease in the bacterial fatty acid (BACT) contribution to the SAT pool was observed in both layers of the vegetated sediment. In contrast, the contribution of these components to the SAT pool was fairly invariable in nonvegetated sediments during the same period (Fig. S4, Table S2).

\subsubsection{Relationship between different physicochemical parameters}

The relationships between $\mathrm{H}_{2} \mathrm{~S}, \mathrm{O}_{2}, \mathrm{TL}, \mathrm{S}^{0}, \mathrm{PA}, E_{h}$ and the UND in vegetated and nonvegetated sediment are shown in the principal component analysis, where PC1 explained $42.5 \%$ and PC2 $14.4 \%$ of variability (Fig. 10). The loadings for positive relationships were obtained for $\mathrm{H}_{2} \mathrm{~S}(0.298)$ on PC1 and $E_{h}(0.541)$ and $\mathrm{O}_{2}(0.327)$ on PC2. For the negative relationships, the loadings were for TL $(-0.534)$, the $\mathrm{UND}(-0.494), \mathrm{S}^{0}(-0.388), E_{h}(-0.327), \mathrm{PA}(-0.296)$ and $\mathrm{O}_{2}(-0.191)$ on $\mathrm{PC} 1$ and $\mathrm{H}_{2} \mathrm{~S}(-0.536), \mathrm{S}^{0}(-0.485)$, TL $(-0.165)$ and the UND $(-0.221)$ on PC2.

PC1 separated most of the upper sediment layers (July 2017-May 2018, September-October 2018) according to the higher TLs and $\mathrm{S}^{0}$, a higher UND, and more positive $E_{h}$ from most of the lower layers and upper layers of vegetated sediments (June-August 2018) with increased $\mathrm{H}_{2} \mathrm{~S}$ concentrations. On PC2, the vegetated was separated from the nonvegetated sediment due to higher concentrations of $\mathrm{H}_{2} \mathrm{~S}$ and $\mathrm{S}^{0}$ and more negative $E_{h}$, which characterized vegetated sediments during almost the entire study period. The extreme concentrations of $\mathrm{S}^{0}$ and $\mathrm{H}_{2} \mathrm{~S}$ found in the upper layer in April and the lower layer in August 2018, respectively, were responsible for the considerable separation of these layers from all other vegetated layers (Fig. 10).

\section{Discussion}

Saline Bay is a shallow, highly dynamic coastal area characterized by frequently turbid waters due to the combined effect of land runoff and wind-driven resuspension of fine sediment. Nutrients and Chl $a$ (as a proxy for autotrophic biomass) varied in the ranges characteristic for the oligotrophic coastal waters off Rovinj (Ivančić et al., 2018). The dynamics of particulate matter were associated with freshwater input. The higher contribution from autochthonous sources was observed during the increases in autotrophic biomass. However, only in September 2017 was this increase supported by nutrients from the water column, while all other increases were most likely connected to bottom waters where phytoplankton could have been supplied with nutrients through sediment resuspension. The considerable increase in the particulate matter of terrigenous origin from April to $\mathrm{Au}-$ gust 2018 suggested the enhanced land runoff in that period.

In temperate Mediterranean coastal waters $C$. nodosa meadows show a clear unimodal annual growth cycle, reaching maximum development in summer and a minima during winter, with a particularly active growth phase in spring (Terrados and Ros, 1992; Zavodnik et al., 1998; Agostini et al., 2003). In Saline Bay, the maximum biomass was measured in October 2017. This shift from summer to early autumn was most likely due to intense grazing activities (Cebrian et 


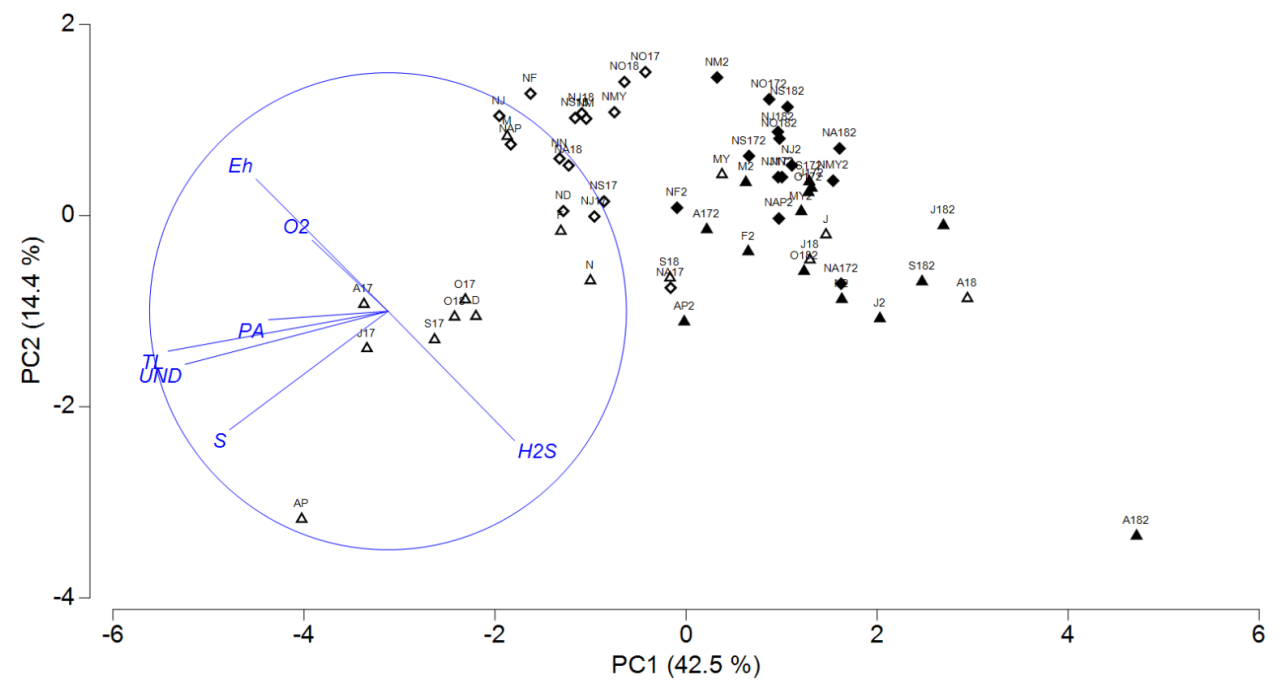

Figure 10. PCA plot of redox potential $\left(E_{h}\right)$, oxygen $\left(\mathrm{O}_{2}\right)$, hydrogen sulfide $\left(\mathrm{H}_{2} \mathrm{~S}\right)$, sulfur $(\mathrm{S})$, total lipid concentration $(\mathrm{TL})$, prokaryotic abundance (PA) and unsaturation degree (UND) in the upper $(0-4 \mathrm{~cm} ; \triangle, \diamond)$ and lower $(5-7 \mathrm{~cm} ; \boldsymbol{\Lambda}, \boldsymbol{\diamond})$ layers of vegetated and nonvegetated sediments, respectively. Projections of variables are given in the circle.

al., 1996; Valentine and Duffy, 2006) suggested by a prevalence of visibly grazed leaves during July and August 2017. A growth minimum occurred during late autumn and winter, as commonly observed. However, during the spring of 2018 , phenological parameters continued to decrease in spite of established favorable environmental conditions for growth, i.e., increase in water temperature, intensity and period of solar radiation. This decrease continued until the complete extinction of the aboveground tissue in August 2018. The belowground tissue followed a similar trend but with less expressed changes. Still, their recognizable remnants were found after the loss of the aboveground tissues.

Organic matter and closely correlated total lipids in the sediment of $C$. nodosa-rooted area changed significantly throughout the investigated period, in contrast to organic matter in nonvegetated sediment. Nevertheless, considerable similarity in the quality and degradation of lipid matter at both the vegetated and the nonvegetated sites indicates an important contribution of detritus imported from the meadow as a source of organic matter for prokaryotes in nonvegetated sediments. This close coupling could be expected due to site proximity and the lower organic content of the nonvegetated sediment, which should enhance the dependence of prokaryotes on the imports of seagrass detritus from the adjacent meadows (Holmer et al., 2004). The significant enrichment of $C$. nodosa sediment with unsaturated, more labile components only during abundant growth of the meadow could be explained by more efficient entrapment of seston material within the meadow (Gacia and Duarte, 2001). Such easily utilizable organic matter, including dissolved monomeric carbohydrates, leaching out during decomposition of $C$. no- dosa leaves stimulated prokaryotic growth as previously observed (Peduzzi and Herndl, 1991).

From July 2017 to March 2018, an adaptation of C. nodosa leaves to the decreasing light and temperature occurred. Until October 2017, the temperature of the water column was still optimal for elongation of the leaves and biomass increase, while the ambient light intensities were continuously decreasing. An additional reduction in available light might occur from the self-shading effect due to high canopy biomass and/or shading due to epiphytic macroalgae growth. Desaturation of low and fairly invariable lipids during the most active growth phase suggested an increase in the membrane fluidity to optimize photosynthetic activity under lowlight conditions. Such a physiological adaptation was found in seagrasses living along a depth gradient (Beca-Carretero et al., 2019) and in macroalgae in contrasting seasons (Schmid et al., 2014). In late autumn 2017 and 2018, the decrease in desaturation indicated reduced fluidity and activity of photosynthetically active membranes (Quigg et al., 2006; Wacker et al., 2016). This was associated with a decreased abundance of shoots and aboveground biomass. By shedding leaves and shoots the plant further balances metabolic requirements and mobilizes energy from the carbohydrate reserves stored in the belowground tissue (Alcoverro et al., 2001; Lee et al., 2007). During the winter, due to a sharp and continuous decrease in water temperature, rapid desaturation of increasing lipids provided cold resistance, as regularly observed in algae and plants (Terrados and Lopez-Jimenez, 1996; Iveša et al., 2004; Upchurch, 2008).

In a healthy seagrass meadow, the oxygen generated by seagrass photosynthesis is transported to belowground tissues to maintain an oxic microsphere around roots and rhi- 
zomes and reoxidize sulfide to nontoxic $\mathrm{S}^{0}$, thus preventing an invasion of $\mathrm{H}_{2} \mathrm{~S}$ into the plant (Pedersen et al., 1998; Holmer et al., 2005). $\mathrm{S}^{0}$ was found in the C. nodosa belowground tissue during the entire investigation period, as already observed in seagrasses living in sulfidic sediments (Holmer and Hasler-Sheetal, 2014; Hasler-Sheetal and Holmer, 2015). The relatively low accumulation of $\mathrm{H}_{2} \mathrm{~S}(<$ $30 \mu \mathrm{M}$ ) during the summer and early autumn 2017 indicated that $\mathrm{H}_{2} \mathrm{~S}$ was apparently rapidly recycled within the rooted area via reoxidation by $\mathrm{O}_{2}$ to $\mathrm{S}^{0}$ and/or removal by precipitation with iron compounds. Most of $\mathrm{S}^{0}$ was found in oxic layers or at suboxic-anoxic boundaries, being in ranges typical for sulfidic coastal sediments (Troelsen and Jørgensen, 1982; Panutrakul et al., 2001; Pjevac et al., 2014). The oxidation of $\mathrm{H}_{2} \mathrm{~S}$ could occur spontaneously by chemical reaction with free oxygen or mediated by sulfide-oxidizing bacteria surrounding or being attached to seagrass roots (Jørgensen, 1977; Cúcio et al., 2016; Ugarelli et al., 2017; Fahimipour et al., 2017). In November, due to the degradation of organic matter and reduced oxygen production and leakage in the rooted zone caused by $C$. nodosa senescence, the reoxidation capacity of the sediment was greatly decreased. This resulted in considerable accumulation of $\mathrm{H}_{2} \mathrm{~S}(>100 \mu \mathrm{M})$ which extended up to the sediment surface. During winter and early spring, $\mathrm{H}_{2} \mathrm{~S}$ production generally decreased, likely due to the reduced activity of sulfate reducing prokaryotes at lower temperatures, and the sediment gradually shifted towards a more oxidized state. $\mathrm{H}_{2} \mathrm{~S}$ detected even within the oxic sediment and in the rooted area in February 2018 could be attributed to the sediment heterogeneity and the presence of reducing microniches where anaerobic metabolism could occur regardless of surrounding redox conditions (Jørgensen, 1977; Frederiksen and Glud, 2006).

In April 2018, C. nodosa was most probably exposed to increased siltation, due to an intensification of terrigenous input as indicated by a decrease in salinity $(\Delta 1.5$ with respect to March) and a substantial increase in particulate matter concentration (up to 3 times more than in March; Fig. 1b) combined with resuspension of sediment, provoking elevated autotrophic growth. The intensive siltation is associated with the increased light attenuation, both through the direct shading effect of suspended sediments and through the promotion of phytoplankton and epiphyte growth by the associated increase in nutrients (Terrados et al., 1998; Halun et al., 2002; Brodersen et al., 2015). Therefore, the increase in seawater turbidity and considerable sediment redeposition on the leaves might have severely impaired the light availability and slowed down the plant's photosynthetic activity as indicated by LA / ALA being more than 1 in the aboveground tissue, resulting from a decreased conversion of LA to ALA (Harris and James, 1965). When the minimum light requirements ( $\sim 14 \%$ of incidence light) are not met, $C$. nodosa intensely sheds leaves and shoots (Collier et al., 2012). Such light conditions apparently persisted until May 2018 and most likely prevented the re-establishment of photosynthesis, and C. no- dosa continued to shed shoots and leaves. The reduced photosynthesis and therefore $\mathrm{O}_{2}$ transport from the leaves to the rhizome-root system probably minimized root respiration. The maintenance of the oxic rhizosphere and the internal $\mathrm{O}_{2}$ partial pressure in the lacunae further depended mainly on the diffusion of $\mathrm{O}_{2}$ from the water column. From April to June $2018, \mathrm{O}_{2}$ in the bottom water drastically decreased. Although in such conditions of limited light and $\mathrm{O}_{2}$ the seagrass might be capable of rapidly modulating metabolic pathways and enhance its photosynthetic rate, as shown for Zostera muelleri (Kim et al., 2018), it appeared that the $\mathrm{O}_{2}$ content of the $C$. nodosa belowground tissue was still too low to maintain the internal pressure, and therefore, the plant tissues became potentially accessible to sulfide intrusion (Pedersen et al., 2004).

At the same time, the sediment was enriched with fresh organic matter derived from increased autotrophic biomass in bottom waters. In addition to the induction of the bloom, strong sediment resuspension, most likely by aeration, stimulated the intense oxidation of $\mathrm{H}_{2} \mathrm{~S}$ that started to be produced in the rooted zone (up to $180 \mu \mathrm{M}$ ), due to increased activity of sulfate-reducing prokaryotes possibly triggered by the increase in temperature. An increase in $\mathrm{S}^{0}$ concentration that reached its maximum in the same layer suggests a simultaneous oxidation of the produced $\mathrm{H}_{2} \mathrm{~S}$. The sulfide oxidation probably caused oxygen depletion in the rooted zone and anoxic zone extension up to the sediment subsurface. In May 2018, the excess of organic matter accumulated in April 2018 was degraded. The concentrations of $\mathrm{S}^{0}$, detected only in the suboxic layer, considerably decreased possibly by disproportionation or respiration by members of the sulfate reducing bacteria (Pjevac et al., 2014).

During June and July 2018, a sudden and significant deterioration in C. nodosa physiological conditions was indicated by the further increase in the LA / ALA ratio in the leaves and by the overall saturation of decreasing lipids in aboveground and belowground tissues. Additionally, the loss of leaf tissue negatively impacted the photosynthetic carbon fixation and therefore oxygen production, including the transport of oxygen to belowground tissue (Lee and Dunton, 1997; Lee et al., 2007). The belowground tissue that was not supported by photosynthetically derived oxygen became anoxic. Thus induced anaerobiosis most likely caused a complete inhibition of the fatty acid desaturation chain (Harris and James, 1965) and a permanent breakdown of photosynthesis leading to the final decay of the aboveground biomass and considerable loss of belowground biomass. As the bottom waters were completely depleted in $\mathrm{O}_{2}$ the whole plant was exposed to sulfides. $\mathrm{H}_{2} \mathrm{~S}$ inhibits cytochrome $\mathrm{c}$ oxidase by binding to regulatory sites on the enzyme, reducing the rate of cellular respiration and leading to the chemical asphyxiation (Nicholls et al., 2013).

From June to August 2018, the decomposition of organic matter, encompassing the entire sediment core, was intensified and accompanied by a large increase in $\mathrm{H}_{2} \mathrm{~S}$ concentra- 
tions (up to $1200 \mu \mathrm{M}$ ). The degradation process involved rhizomes and roots, as suggested by the apparent loss of belowground biomass. Such loss typically occurs in the first stage of plant decay, the leaching phase (Trevathan-Tackett et al., 2017). Readily available, soluble carbohydrates that largely contribute to the leachate mass (Vichkovitten and Holmer, 2004) most probably supported the increase in prokaryotic abundance observed in June and July 2018. However, the significant decrease in prokaryotic abundance that coincided with a maximum degradation of organic matter and $\mathrm{H}_{2} \mathrm{~S}$ production in August 2018 might indicate that remaining compounds were not degradable by the sulfate reduction pathway (Arndt et al., 2013) and needed the presence of prokaryotes specialized in the anaerobic degradation of refractory compounds, including cellulose and lignin.

During September and October 2018, $\mathrm{H}_{2} \mathrm{~S}$ concentrations drastically decreased, and the sediment was gradually enriched in fresh organic matter. Due to the combined effect of freshened oxygenated water inflow and resuspension which gradually deepened the oxic layer, reoxidation of $\mathrm{H}_{2} \mathrm{~S}$ increased. Biogeochemical studies suggest that most sulfides (80\%-90\%) are eventually reoxidized; $10 \%-20 \%$ are ultimately buried as complexes with iron (i.e., $\mathrm{FeS}, \mathrm{FeS}_{2}$ ) or with organic matter after sulfurization (Jørgensen, 1977, 1982). $\mathrm{H}_{2} \mathrm{~S}$ scavenging with iron and formation of iron sulfides might be more important in Saline Bay, since terrestrial waters are washing out terra rossa, rich in Fe oxides and oxyhydroxides (Durn, 2003). For this reason, sediment cores were most likely always black with sulfuric odor, irrespective of $\mathrm{H}_{2} \mathrm{~S}$ concentrations or the presence of vegetation.

\section{Conclusions}

Our results provide insights into the interaction of multiple stressors that have led to the meadow decay, triggered in the sensitive recruitment phase of meadow growth. Even after the improvement of the sediment conditions by the end of the summer of 2018, C. nodosa was not able to recolonize its previously occupied areas. This finding combined with a visible alteration of the water column and sediment indicates a considerable loss of the $C$. nodosa habitat. Further research is needed to examine the fate of Saline Bay meadows and an eventual recolonization of the area.

Beyond seagrass itself, this loss had extensive consequences as it has endangered many species that depend on seagrass for food, shelter and nursery. Given the lack of data on the ecological and conservation status of the still numerous seagrass meadows along the northern Adriatic coast, the identification and monitoring of the main pressures acting on them are needed to protect such valuable habitats from degradation and extinction.
Data availability. The underlying data sets presented as figures and tables within this paper and the Supplement are available upon request by contacting the corresponding author.

Supplement. The supplement related to this article is available online at: https://doi.org/10.5194/bg-17-3299-2020-supplement.

Author contributions. MN, MK and GJH conceptualized the study; the investigation was carried out by MK, PP, MM, II, LI, IF and MN; $\mathrm{MN}$ conducted formal analysis and wrote the original draft, which was reviewed and edited by MK, GJH, PP, LI, II, IF and MM.

Competing interests. The authors declare that they have no conflict of interest.

Acknowledgements. We sincerely thank Jasna Jakovčević and Margareta Buterer for nutrient and chlorophyll $a$ determination and Andrea Budiša and Ines Haberle for occasional help during the separation and biometry of plant material. We highly appreciate the detailed comments and constructive suggestions by Kunshan Gao, the anonymous referee and Minhan Dai.

Financial support. Financial support was provided by the Croatian Science Foundation to Mirjana Najdek (project IP-2016-06-7118, MICRO-SEAGRASS).

Review statement. This paper was edited by Minhan Dai and reviewed by Kunshan Gao and one anonymous referee.

\section{References}

Agostini, S., Pergent, G., and Marchand, B.: Growth and primary production of Cymodocea nodosa in a coastal lagoon, Aquat. Bot., 76, 185-193, 2003.

Alcoverro, T., Manzanera, M., and Romero, J.: Annual metabolic carbon balance of the seagrass Posidonia oceanica: the importance of carbohydrate reserves, Mar. Ecol.-Prog. Ser., 211, 105116, 2001.

Arndt, S., Jørgensen, B. B., LaRowe, D. E., Middelburg, J. J., Pancost, R. D., and Regnier, P.: Quantifying the degradation of organic matter in marine sediments: A review and synthesis, EarthSci. Rev., 123, 53-86, 2013.

Beca-Carretero, P., Guihéneuf, F., Marín-Guirao, L., BernardeauEsteller, J., García-Muñoz, R., Stengel, D. B., and Ruiz, J. M.: Effects of an experimental heat wave on fatty acid composition in two Mediterranean seagrass species, Mar. Pollut. Bull., 134, 27-37, 2018.

Beca-Carretero, P., Guihéneuf, F., Winters, G., and Stengel, D. B.: Depth-induced adjustment of fatty acid and pigment composition suggests high biochemical plasticity in the tropical seagrass Halophila stipulacea, Mar. Ecol.-Prog. Ser., 608, 105-117, 2019. 
Borum, J., Pedersen, O., Greve, T. M., Frankovich, T. A., Zieman, J. C., Fourqurean, J. W., and Madden, C. J.: The potential role of plant oxygen and sulphide dynamics in die-off events of the tropical seagrass, Thalassia testudinum, J. Ecol., 93, 148-158, 2005.

Bourbonniere, R. A. and Meyers, P. A.: Sedimentary geolipid records of historical changes in the watersheds and productivities of Lakes Ontario and Erie, Limnol. Oceanogr., 41, 352-359, 1996.

Brodersen, K. E., Lichtenberg, M., Paz, L.-C., and Kühl, M.: Epiphyte-cover on seagrass (Zostera marina L.) leaves impedes plant performance and radial $\mathrm{O}_{2}$ loss from the bellow-ground tissue, Front. Mar. Sci., 2, 58, https://doi.org/10.3389/fmars.2015.00058, 2015.

Cancemi, G., Buia, M. C., and Mazzella, L.: Structure and growth dynamics of Cymodocea nodosa meadows, Sci. Mar., 66, 365373, 2002.

Canfield, D. E., Jørgensen, B. B., Fossing, H., Glud, R., Gundersen, J., Ramsing, N. B., Thamdrup, B., Hansen, J. W., Nielsen, L. P., and Hall, P. O. J.: Pathways of organic carbon oxidation in three continental margin sediments, Mar. Geol., 113, 27-40, 1993.

Capone, D. G. and Kiene, R. P.: Comparison of microbial dynamics in marine and freshwater sediments: Contrasts in anaerobic carbon catabolism, Limnol. Oceanogr., 33, 725-749, 1988.

Carlson, P. R., Yarbro, L. A., and Barber, T. R.: Relationship of sediment sulfide to mortality of Thalassia testudinum, Florida Bay, B. Mar. Sci., 54, 733-746, 1994.

Cebrian, J., Duarte, C. M., and Marbà, N.: Herbivory on the seagrass Cymodocea nodosa (Ucria) Ascherson in contrasting Spanish Mediterranean habitats, J. Exp. Mar. Biol. Ecol., 204, 103$111,1996$.

Cline, J. D.: Spectrophotometric determination of hydrogen sulfide in natural waters, Limnol. Oceanogr., 14, 454-458, 1969.

Collier, C. J., Lavery, P. S., Masini, R. J., and Ralph, P. J.: Shadeinduced response and recovery of the seagrass Posidonia sinuosa, J. Exp. Mar. Biol. Ecol., 370, 89-103, 2009.

Collier, J. C., Waycott, M., and Giraldo Ospina, A.: Responses of four Indo-West Pacific seagrass species to shading, Mar. Pollut. Bull., 65, 342-354, 2012.

Costa, M. M., Barrote, I., Silva, J., Olivé, I., Alexandre, A., Albano, S., and Santos, R.: Epiphytes modulate Posidonia oceanica photosynthetic production, energetic balance, antioxidant mechanisms, and oxidative damage, Front. Mar. Sci., 2, 111, https://doi.org/10.3389/fmars.2015.00111, 2015.

Cranwell, P. A., Eglinton, G., and Robinson, N.: Lipids of aquatic organisms as potential contributors to lacustrine sediments, Org. Geochem., 11, 513-527, 1987.

Cúcio, C., Engelen, A. H., Costa, R., and Muyzer, G.: Rhizosphere Microbiomes of European Seagrasses Are Selected by the Plant, But Are Not Species Specific, Front. Microbiol., 7, 440, https://doi.org/10.3389/fmicb.2016.00440, 2012.

Duarte, C. M., Kennedy, H., Marbà, N., Gacia, E., Fourqurean, J. W., Beggins, J., Barrón, C., and Apostolaki, E. T.: Seagrass community metabolism: Assessing the capacity of seagrass meadows for carbon burial: Current limitations and future strategies, Ocean Coast. Manage., 83, 32-38, 2013.

Durn, G.: Terra Rossa in the Mediterranean Region: Parent Materials, Composition and Origin, Geol. Croat., 56, 83-100, 2003.
Epstein, S. S. and Rossel, J.: Enumeration of sandy sediment bacteria: search for optimal protocol, Mar. Ecol.-Prog. Ser., 117, 289298, 1995.

Fahimipour, A. K., Kardish, M. R., Lang, J. M., Green, J. L., Eisen, J. A., and Stachowicz, J. J.: Global-Scale Structure of the Eelgrass Microbiome, Appl. Environ. Microb., 83, e03391-16, https://doi.org/10.1128/AEM.03391-16, 2017.

Folk, R. L.: The distinction between grain size and mineral composition in sedimentary-rock nomenclature, J. Geol., 62, 344-359, 1954.

Frederiksen, M. S. and Glud, R. N.: Oxygen dynamics in the rhizosphere of Zostera marina: A two-dimensional planar optode study, Limnol. Oceanogr., 51, 1072-1083, 2006.

Gacia, E. and Duarte, C. M.: Sediment Retention by a Mediterranean Posidonia oceanica Meadow: The Balance between Deposition and Resuspension, Estuar. Coast. Shelf. S., 52, 505-514, 2001.

Gangi, A. F.: Permeability of unconsolidated sands and porous rocks, J. Geophys. Res.-Solid, 90, 3099-3104, 1985.

Gao, G., Clare, A. S., Chatzidimitriou, E., Rose, C., and Caldwell, G.: Effects of ocean warming and acidification, combined with nutrient enrichment, on chemical composition and functional properties of Ulva rigida, Food Chem., 258, 71-78, 2018.

Halun, Z., Terrados, J., Borum, J., Kamp-Nielsen, J., Duarte, C. M., and Fortes, M. D.: Experimental evaluation of the effects of siltation-derived changes in sediment conditions on the Philippine seagrass Cymodocea rotundata, J. Exp. Mar. Biol. Ecol., 279, 73-87, 2002.

Harris, R. V. and James, A. T.: Linoleic and $\alpha$-linolenic acid biosynthesis in plant leaves and a green alga, Biochim. Biophys. Acta, 106, 456-464, 1965.

Hasler-Sheetal, H. and Holmer, M.: Sulfide intrusion and detoxification in the seagrass Zostera marina, Plos One, 10, e0129136, https://doi.org/10.1371/journal.pone.0129136, 2015.

Hendriks, I. E., Sintes, T., Bouma, T. J., and Duarte, C. M.: Experimental assessment and modeling evaluation of the effects of the seagrass Posidonia oceanica on flow and particle trapping, Mar. Ecol.-Prog. Ser., 356, 163-173, 2008.

Holm-Hansen, O., Lorenzen, C. J., Holmes, R. W., and Strickland, J. D. H.: Fluorometric determination of chlorophyll, J. Conseil., 301, 3-15, 1965.

Holmer, M. and Hasler-Sheetal, H.: Sulfide intrusion in seagrasses assessed by stable isotopes- a synthesis of current results, Front. Mar. Sci., 1, 64, https://doi.org/10.3389/fmars.2014.00064, 2014.

Holmer, M. and Nielsen, S. L.: Sediment sulfur dynamics related to biomass-density pattern in Zostera marina (eelgrass) beds, Mar. Ecol.-Prog. Ser., 146, 163-171, 1997.

Holmer, M., Duarte, C. M., Boschker, H. T. S., and Barrón, C.: Carbon cycling and bacterial carbon sources in pristine and impacted Mediterranean seagrass sediments, Aquat. Microb. Ecol., 36, 227-237, 2004.

Holmer, M., Frederiksen, M. S., and Møllegaard, H.: Sulfur accumulation in eelgrass (Zostera marina) and effect of sulfur on eelgrass growth, Aquat. Bot., 81, 367-379, 2005.

Ivančić, I., Paliaga, P., Pfannkuchen, M., Đakovac, T., Najdek, M., Steiner, P., Korlević, M., Markovski, M., Baričević, A., Smodlaka Tanković, M., and Herndl, G. J.: Seasonal variations in extracellular enzymatic activity in marine 
snow-associated microbial communities and their impact on the surrounding water, FEMS Microbiol. Ecol., 94, fyi198, https://doi.org/10.1093/femsec/fiy198, 2018.

Iveša, Lj., Blažina, M., and Najdek, M.: Seasonal variations in fatty acid composition of Caulerpa taxifolia (M. Vahl.) C. Ag. in the northern Adriatic Sea (Malinska, Croatia), Bot. Mar., 47, 209214, 2004.

Jørgensen, B. B.: The sulfur cycle of a coastal marine sediment (Limfjorden, Denmark), Limnol. Oceanogr., 22, 814-832, 1977.

Jørgensen, B. B.: Mineralization of organic matter in the sea bed the role of sulphate reduction, Nature, 296, 643-645, 1982.

Kim, M., Brodersen, K. E., Szabó, M., Larkum, A. W. D., Raven J. A., Ralph, P. J., and Pernice, M.: Low oxygen affects photophysiology and the level of expression of two-carbon metabolism genes in the seagrass Zostera muelleri, Photosynth. Res., 136, 147-160, 2018.

Koch, M. S. and Erskine, J. M.: Sulfide as a Phytotoxin to the Tropical Seagrass Thalassia testudinum: Interactions with Light, Salinity and Temperature, J. Exp. Mar. Biol. Ecol., 266, 81-95, 2001.

Krause-Jensen, D., Carstensen, J., Nielsen, S. L., Dalsgaard, T., Christensen, P. B., Fossing, H., and Rasmussen, M. B.: Sea bottom characteristics affect depth limits of eelgrass Zostera marina, Mar. Ecol.-Prog. Ser., 425, 91-102, 2011.

Lee, K.-S. and Dunton, K. H.: Diurnal changes in pore water sulfide concentrations in the seagrass Thalassia testudinum beds: the effects of seagrasses on sulfide dynamics, J. Exp. Mar. Biol. Ecol., 255, 201-214, 2000.

Lee, K.-S., Park, S. R., and Kim, Y. K.: Effects of irradiance, temperature, and nutrients on growth dynamics of seagrasses: A review, J. Exp. Mar. Biol. Ecol., 350, 144-175, 2007.

Marbà, N. and Duarte, C. M.: Growth and sediment space occupation by seagrass Cymodocea nodosa roots, Mar. Ecol.-Prog. Ser., 224, 291-298, 2001.

Mascaró, O., Valdemarsen, T., Holmer, M., Pérez, M., and Romero, J.: Experimental manipulation of sediment organic content and water column aeration reduces Zostera marina (eelgrass) growth and survival, J. Exp. Mar. Biol. Ecol., 373, 26-34, 2009.

Micromeritics: SediGraph 5100 particle size analysis system operator' manual, Micromeritics Instrument Corporation, Norcross, 2002.

Moeslund, L., Thamdrup, B., and Jørgensen, B. B.: Sulfur and iron cycling in a coastal sediment - radiotracer studies and seasonal dynamics, Biogeochemistry, 27, 129-152, 1994.

Nicholls, P., Marshall, D. C., Cooper, C. E., and Wilson, M. T.: Sulfide inhibition of and metabolism by cytochrome c oxidase, Biochem. Soc. T., 41, 1312-1316, 2013.

Orlando-Bonaca, M., Francé, J., Mavrič, B., Grego, M., Lipej, L., Flander Putrle, V., Šiško, M., and Falace, A.: A new index (MediSkew) for the assessment of the Cymodocea nodosa (Ucria) Ascherson meadow's status, Mar. Environ. Res., 110, 132-141, 2015.

Orlando-Bonaca, M., Francé, J., Mavrič, B., and Lipej, L.: Impact of the Port of Koper on Cymodocea nodosa meadow, Annales, 29, 187-194, 2019.

Orth, R. J., Carruthers, T. J. B., Dennison, W. C., Duarte, C. M., Fourqurean, J. W., Heck Jr., K. L., Hughes, A. R., Kendrick, G. A., Kenworthy, E. J., Olyarnik, S., Short, F. T., Waycott, M., and
Williams, S. L.: A Global Crisis for Seagrass Ecosystems, BioScience, 56, 987-996, 2006.

Panutrakul, S., Monteny, F., and Baeyens, W.: Seasonal Variations in Sediment Sulfur Cycling in the Ballastplaat Mudflat, Belgium, Estuaries, 24, 257-265, 2001.

Pedersen, M. F., Duarte, C. M., and Cebrián, J.: Rates of changes in organic matter and nutrient stocks during seagrass Cymodocea nodosa colonization and stand development, Mar. Ecol.-Prog. Ser., 159, 29-36, 1997.

Pedersen, O., Borum, J., Duarte, C. M., and Fortes, M. D.: Oxygen dynamics in the rhizosphere of Cymodocea rotundata, Mar. Ecol.-Prog. Ser., 169, 283-288, 1998.

Pedersen, O., Binzer, T., and Borum, J.: Sulphide intrusion in eelgrass (Zostera marina L.), Plant Cell Environ., 27, 595-602, 2004.

Peduzzi, P. and Herndl, G. J.: Decomposition and significance of seagrass litter (Cymodocea nodosa) for the microbial food web in coastal waters (Gulf of Trieste, Northern Adriatic Sea), Mar. Ecol.-Prog. Ser., 71, 163-174, 1991.

Pérez, M., Invers, O., Ruiz Fernandez, J. M., Frederiksen, M., and Holmer, M.: Physiological responses of the seagrass Posidonia oceanica to elevated organic matter content in sediments: An experimental assessment, J. Exp. Mar. Biol. Ecol., 344, 149-160, 2007.

Pirini, M., Manuzzi, M. P., Pagliarani, A., Trombetti, F., Borgatti, A. R., and Ventrella, V.: Changes in fatty acid composition of Mytilus galloprovincialis (Lmk) fed on microalgal and wheat germ diets, Comp. Biochem. Phys. B, 147, 616-626, 2007.

Pjevac, P., Kamyshny Jr., A., Dyksma, S., and Mussmann, M.: Microbial consumption of zero-valence sulfur in marine benthic habitats, Environ. Microbiol., 16, 3416-3430, 2014.

Porter, K. G. and Feig, Y. S.: The use of DAPI for identification and counting aquatic microflora, Limnol. Oceanogr., 25, 943984, 1980.

Quigg, A., Kevekordes, K., Raven, J., and Beardall, J.: Limitations on microalgal growth at very low photon fluency rates: the role of energy slippage, Photosynth. Res., 88, 299-310, 2006.

Rogowska, J., Sychowska, J., Cieszynska-Semenowicz, M., and Wolska, L.: Elemental sulfur in sediments: analytical problems, Environ. Sci. Pollut. Res., 23, 24871-24879, 2016.

Samper-Villarreal, J., Lovelock, C. E., Saunders, M. I., Roelfsema, C., and Mumby, P. J.: Organic carbon in seagrass sediment is influenced by seagrass canopy complexity, turbidity, wave height, and water depth, Limnol. Oceanogr., 61, 938-952, 2016.

Schmid, M., Guihéneuf, F., and Stengel, D. B.: Fatty acid contents and profiles of 16 macroalgae collected from the Irish Coast at two seasons, J. Appl. Phycol., 26, 451-463, 2014.

Short, F. T., Polidoro, B., Livingstone, S. R., Carpenter, K. E., Bandeira, S., Bujang, J. S., Calumpong, H. P., Carruthers, T. J. B., Coles, R. G., Dennison, W. C., Erftemeijer, P. L. A., Fortes, M. D., Freeman, A. S., Jagtap, T. G., Kamal, A. M., Kendrick, G. A., Kenworthy, W. J., La Nafie, Y. A., Nasution, I. M., Orth, R. J., Prathep, A., Sanciangco, J. C., van Tussenbroek, B., and Vergara, S. G.: Extinction risk assessment of the world's seagrass species, Biol. Conserv., 144, 1961-1971, 2011.

Sousa, A. I., Calado, R., Cleary, D. F. R., Nunes, C., Coimbra, M. A., Serôdio, J., and Lillebø, A. I.: Effect of spatio-temporal shifts in salinity combined with other environmental variables on the ecological processes provided by Zostera noltii meadows, Sci. 
Rep.-UK, 7, 1336, https://doi.org/10.1038/s41598-017-01359-2, 2017.

Strickland, J. D. H. and Parsons, T. R.: A practical handbook of seawater analysis, Bull. Fish. Res. Board. Can., 167, 1-310, 1972.

Terrados, J. and Lopez-Jimenez, J. A.: Fatty acid composition and chilling resistance in the green alga Caulerpa prolifera (Forrskal) Lamouroux (Chlorophyta, Caulerpales), Biochem. Mol. Biol. Int., 39, 863-869, 1996.

Terrados, J. and Ros, J. D.: Growth and primary production of $C y$ modocea nodosa (Ucria) Ascherson in a Mediterranean coastal lagoon: the Mar Menor (SE Spain), Aquat. Bot., 43, 63-74, 1992.

Terrados, J., Duarte, C. M., Fortes, M. D., Borum, J., Agawin, N. S. R., Bach, S., Thampanya, U., Kamp-Nielsen, L., Kenworthy, W. J., Geertz-Hansen, O., and Vermaat, J.: Changes in Community Structure and Biomass of Seagrass Communities along Gradients of Siltation in SE Asia, Estuar. Coast. Shelf S., 46, 757-768, 1998.

Trevathan-Tackett, S. M., Seymour, J. R., Nielsen, D. A., Macreadie, P. I., Jeffries, T. C., Sanderman, J., Baldock, J., Howes, J. M., Steven, A. D. L., and Ralph, P. J.: Sediment anoxia limits microbial-driven seagrass carbon remineralization under warming conditions, FEMS Microbiol. Ecol., 93, fix033, https://doi.org/10.1093/femsec/fix033, 2017.

Troelsen, H. and Jørgensen, B. B.: Seasonal dynamics of elemental sulfur in two coastal sediments, Estuar. Coast. Shelf S., 15, 255266, 1982.

Tuya, F., Martín, J. A., and Luque, A.: Impact of a marina construction on seagrass bed at Lanzarote (Canary Islands), J. Coast. Conserv., 8, 157-162, 2002.

Tuya, F., Ribeiro-Leite, L., Arto-Cuesta, N., Coca, J., Haroun, R., and Espino, F.: Decadal changes in the structure of Cymodocea nodosa seagrass meadows: Natural vs. human influences, Estuar. Coast. Shelf S., 137, 41-49, 2014.

Ugarelli, K., Chakrabarti, S., Laas, P., and Stingl, U.: The seagrass holobiont and its microbiome, Microorganisms, 5, 81, https://doi.org/10.3390/microorganisms5040081, 2017.
Upchurch, R. G.: Fatty acid unsaturation, mobilization, and regulation in the response of plants to stress, Biotechnol. Lett., 30, 967-977, 2008.

Valentine, J. F. and Duffy, J. E.: The central role of grazing in seagrass ecology. In: Seagrasses: Biology, Ecology and Conservation, Springer, the Netherlands, 431-501, 2006.

Vaquer-Sunyer, R. and Duarte, C. M.: Thresholds of hypoxia for marine biodiversity, P. Natl. Acad. Sci. USA, 105, 15452-15457, 2008.

Vaquer-Sunyer, R. and Duarte, C. M.: Sulfide exposure accelerates hypoxia-driven mortality, Limnol. Oceanogr., 55, 1075-1082, 2010.

Vichkovitten, T. and Holmer, M.: Contribution of plant carbohydrates to sedimentary carbon mineralization, Org. Geochem., 35, 1053-1066, 2004.

Viso, A. C., Pesando, D., Bernard, P., and Marty, J. C.: Lipid components of the Mediterranean seagrass Posidonia oceanica, Mar Pollut. Bull., 34, 381-387, 1993.

Wacker, A., Piepho, M., Harwood, J. L., Guschina, I. A., and Arts, M. T.: Light-induced changes in fatty acid profiles of specific lipid classes in several freshwater phytoplankton species, Front. Plant Sci., 7, 264, https://doi.org/10.3389/fpls.2016.00264, 2016.

Widdows, J., Pope, N. D., Brinsley, M. D., Asmus, H., and Asmus, R. M.: Effects of seagrass beds (Zostera noltii and Z. marina) on near-bed hydrodynamics and sediment resuspension, Mar. Ecol.Prog. Ser., 358, 125-136, 2008.

Zavodnik, N., Travizi, A., and De Rosa, S.: Seasonal variations in the rate of photosynthetic activity and chemical composition of the seagrass Cymodocea nodosa (Ucr.), Asch. Sci. Mar., 62, 301309, 1998. 